University of South Florida

DIGITAL COMMONS

Digital Commons @ University of

@ UNIVERSITY OF SOUTH FLORIDA

South Florida

$10-1-2000$

\title{
Orbitally Induced Climate and Geochemical Variability Across the Oligocene/Miocene Boundary
}

Hilary A. Paul

Swiss Federal Institute of Technology

James C. Zachos

University of California, Santa Cruz

Benjamin P. Flower

University of South Florida, bflower@marine.usf.edu

Aradhna Tripati

University of California, Santa Cruz

Follow this and additional works at: https://digitalcommons.usf.edu/msc_facpub

Part of the Marine Biology Commons

\section{Scholar Commons Citation}

Paul, Hilary A.; Zachos, James C.; Flower, Benjamin P.; and Tripati, Aradhna, "Orbitally Induced Climate and Geochemical Variability Across the Oligocene/Miocene Boundary" (2000). Marine Science Faculty Publications. 22.

https://digitalcommons.usf.edu/msc_facpub/22

This Article is brought to you for free and open access by the College of Marine Science at Digital Commons @ University of South Florida. It has been accepted for inclusion in Marine Science Faculty Publications by an authorized administrator of Digital Commons @ University of South Florida. For more information, please contact digitalcommons@usf.edu. 


\title{
Orbitally induced climate and geochemical variability across the Oligocene/Miocene boundary
}

\author{
Hilary A. Paul, ${ }^{1}$ James C. Zachos, ${ }^{2}$ Benjamin P. Flower, ${ }^{3}$ and Aradhna Tripati ${ }^{2}$
}

\begin{abstract}
To assess the influence of orbital-scale variations on late Oligocene to early Miocene climate and ocean chemistry, high-resolution ( $\sim 5 \mathrm{kyr})$ benthic foraminiferal carbon and oxygen isotope and percent coarse fraction time series were constructed for Ocean Drilling Program site 929 on Ceara Rise in the western equatorial Atlantic. These time series exhibit pervasive low- to high-frequency variability across a 5-Myr interval (20.5-25.4 Ma). The records also reveal several large-scale secular variations including two positive $(\sim 1.6 \%)$ oxygen isotope excursions at 22.95 and 21.1 Ma, suggestive of large but brief glacial maxima (Mi-1 and Mi-1a events of Miller et al. [1991]), and a long-term cyclical increase in the carbon isotopic composition of seawater (shift of $\sim 1.52 \%$ ) that reaches a maximum coincident with peak $\delta^{18} \mathrm{O}$ values at $22.95 \mathrm{Ma}$. Lower-resolution $(-25 \mathrm{kyr}$ ) records constructed from benthic and planktonic foraminifera as well as bulk carbonate at a shallower site on Ceara Rise (site 926) for the period 21.7-24.9 Ma covary with site $929 \delta^{18} \mathrm{O}$ values reflecting changes in Antarctic ice-volume. Likewise, covariance among carbon isotopic records of bulk sediment, benthic, and planktonic foraminifera suggest that the low-frequency cycles $(\sim 400 \mathrm{kyr})$ and long-term increase in $\delta^{13} \mathrm{C}$ values represent changes in the mean carbon composition of seawater $\Sigma \mathrm{CO}_{2}$. The time series presented here constitute the longest, most continuous, and highestresolution records of pre-Pliocene climate and oceanography to date. The site 929 carbon and oxygen isotope power spectra show significant concentrations of variance at $\sim 400,100$, and $41 \mathrm{kyr}$, demonstrating that orbitally induced oscillations have been a normal characteristic of the global climate system since at least the Oligocene, including periods of equable climate and times with no apparent Northern Component Water production.
\end{abstract}

\section{Introduction}

Since the confirmation of the importance of orbital forcing on Pleistocene climate variability [Hays et al., 1976], researchers have focused on developing a more detailed record of how climate has varied over time. This effort is driven in part by the need to understand the nature and evolution of climatic response to orbital forcing and in an attempt to differentiate between the influence of internal versus external climate forcing factors. Much of our current understanding of how the climate system has responded to orbital forcing is based on studies of Plio-Pleistocene sediments, most notably in marine records of benthic foraminiferal $\delta^{18} \mathrm{O}$ and $\delta^{13} \mathrm{C}$, calculated sea surface temperature (SST), and percent calcium carbonate $\left(\mathrm{CaCO}_{3}\right)$ content of sediments [Shackleton and Opdyke, 1976; Imbrie et al., 1984; Ruddiman et al., 1986, 1989; Hilgen, 1991].

In contrast, little is known about climate variability on finer, $10^{5}$-year ( orbital) timescales from intervals earlier in the Cenozoic, for instance, during intervals of unipolar glaciation or with different modes of circulation, when the nonlinear response of the climate system may have been less enhanced [Imbrie et al., 1993]. Most pre-Pliocene time series lack adequate resolution and length to delineate the higher-

\footnotetext{
'Geological Institute, Swiss Federal Institute of Technology, ETHZentrum, Zürich, Switzerland.

${ }^{2}$ Earth Science Department, University of California, Santa Cruz.

${ }^{3}$ Department of Marine Science, University of South Florida, St. Petersburg.
}

Copyright 2000 by the American Geophysical Union.

Paper number 1999PA000443.

0883-8305/00/1999PA000443\$12.00 and lower-frequency oscillations associated with orbital forcing. While a few investigations have provided evidence suggestive of orbitally induced variations in global climate in the middle Miocene [Pisias et al., 1985] and in the early Oligocene [Mead et al., 1986; Zachos et al., 1996], most studies lack the resolution with which to resolve the higherfrequency variations in climate (for instance, 41-kyr cycles). Low-resolution sampling may result in signal aliasing, potentially producing spurious low-frequency signals [Pisias and Mix, 1988]. As a result, the nature of the environmental response to orbital forcing under boundary conditions significantly different than today remains largely unknown.

The late Oligocene to early Miocene was a period characterized by relative global warmth and possibly higher atmospheric carbon dioxide $\left(\mathrm{CO}_{2}\right)$ levels [Freeman and Hayes, 1992; Pagani et al., 1999]. Antarctica was only partially glaciated, and Northern Hemisphere ice sheets had probably not yet developed [Kennett, 1977; Miller et al., 1987], and as a result, sea level was higher [Haq et al., 1987]. Miller et al. [1991] and Wright and Miller [1992] have identified twelve significant $\delta^{18} \mathrm{O}$ increases $(0.50 \%$ to $>1.0 \%$ o in Oligocene and early late Miocene benthic foraminiferal records (classified as $\mathrm{Oi}$ and Mi zones) that they interpret as large, transient Antarctic glaciations. The first and most prominent of these oxygen isotope excursions in the Miocene, Mi-1 [Miller et al., 1991], occurred near the Oligocene/Miocene $(\mathrm{O} / \mathrm{M})$ boundary. In addition, these intervals appear to coincide with periods of increased oceanic $\delta^{13} \mathrm{C}$ as recorded in benthic foraminifera [Miller and Fairbanks, 1985; Woodruff and Savin, 1991; Hodell and Woodruff, 1994] that are suspected to be linked to changes in the global carbon cycle, possibly indicating periods of increased organic carbon burial in the deep sea. Significant differences between modern and late Oligocene to early 
Miocene deepwater circulation patterns have also been documented, with most studies suggesting the presence of only one major deepwater source in the Atlantic sector of the Southern Ocean, with strong northward flow dominating both the deep Atlantic and Pacific basins until the middle Miocene [Woodruff and Savin, 1989; Wright et al., 1992; Wright and Miller, 1993; Flower et al., 1997a].

The very nature of these apparent global-scale climatic and carbon cycle changes, as well as their relation to orbital forcing, remains a mystery. This study attempts to document in unprecedented detail the rate and degree of change in global and regional climate and ocean chemistry across the Oligocene/Miocene boundary, particularly during the Mi-1 event, on Milankovitch timescales. To this end, highresolution $(-5 \mathrm{kyr})$ carbon and oxygen stable isotope and percent coarse fraction time series were generated for site 929 (4358 m water depth) drilled on Ceara Rise during Ocean Drilling Program (ODP) Leg 154 in the western equatorial Atlantic [Flower et al., 1997b; Paul, 1997; Zachos et al., 1997]. To evaluate further the nature of variability in the oxygen and carbon isotope time series, we lengthened the original site 929 time series by an additional $3.2 \mathrm{Myr}$ and augmented these with lower-resolution ( $-25 \mathrm{kyr}$ ) records from ODP site 926 (3598 m water depth), also on Ceara Rise. Records generated from benthic and planktonic foraminiferal species as well as bulk sediment samples are included to constrain variations in water column isotopic gradients. In addition, spectral analyses of the high-resolution site 929 time series are used to identify the principle components of climatic and geochemical variance.

\subsection{Site Location and Lithology}

Sites 929 (Hole 929A: $5^{\circ} 58^{\prime} \mathrm{N}, 4^{\circ} 44^{\prime} \mathrm{W}, 4358 \mathrm{~m}$ water depth) and 926 (Hole 926B: $3^{\circ} 43^{\prime} \mathrm{N}, 42^{\circ} 54^{\prime} \mathrm{W}, 3598 \mathrm{~m}$ water depth) were drilled during ODP Leg 154 as part of a five-site depth transect on Ceara Rise in the western equatorial Atlantic (Figure 1). Extended core barrel (XCB) drilling yielded better than $91 \%$ core recovery at both sites, thus providing continuous successions across the Oligocene/Miocene boundary. Stratigraphic correlation between sites is based on biostratigraphic markers and standard shipboard physical property data. The exact paleodepths of these sites cannot be precisely calculated owing to uncertain regional tectonic and subsidence history of the plateau, though the rise has probably undergone little subsidence since the early Miocene.

Sedimentation rates at sites 926 and 929 average 26 and 18 $\mathrm{m} / \mathrm{Myr}$, respectively (Table 1) over the interval studied. Upper Oligocene to lower Miocene carbonate content (percent $\mathrm{CaCO}_{3}$ ) at these sites varies from 60 to $80 \%$ at site 926 and from 35 to $75 \%$ at site 929 [Curry et al., 1995]. Concentrations of biosiliceous fragments in some intervals
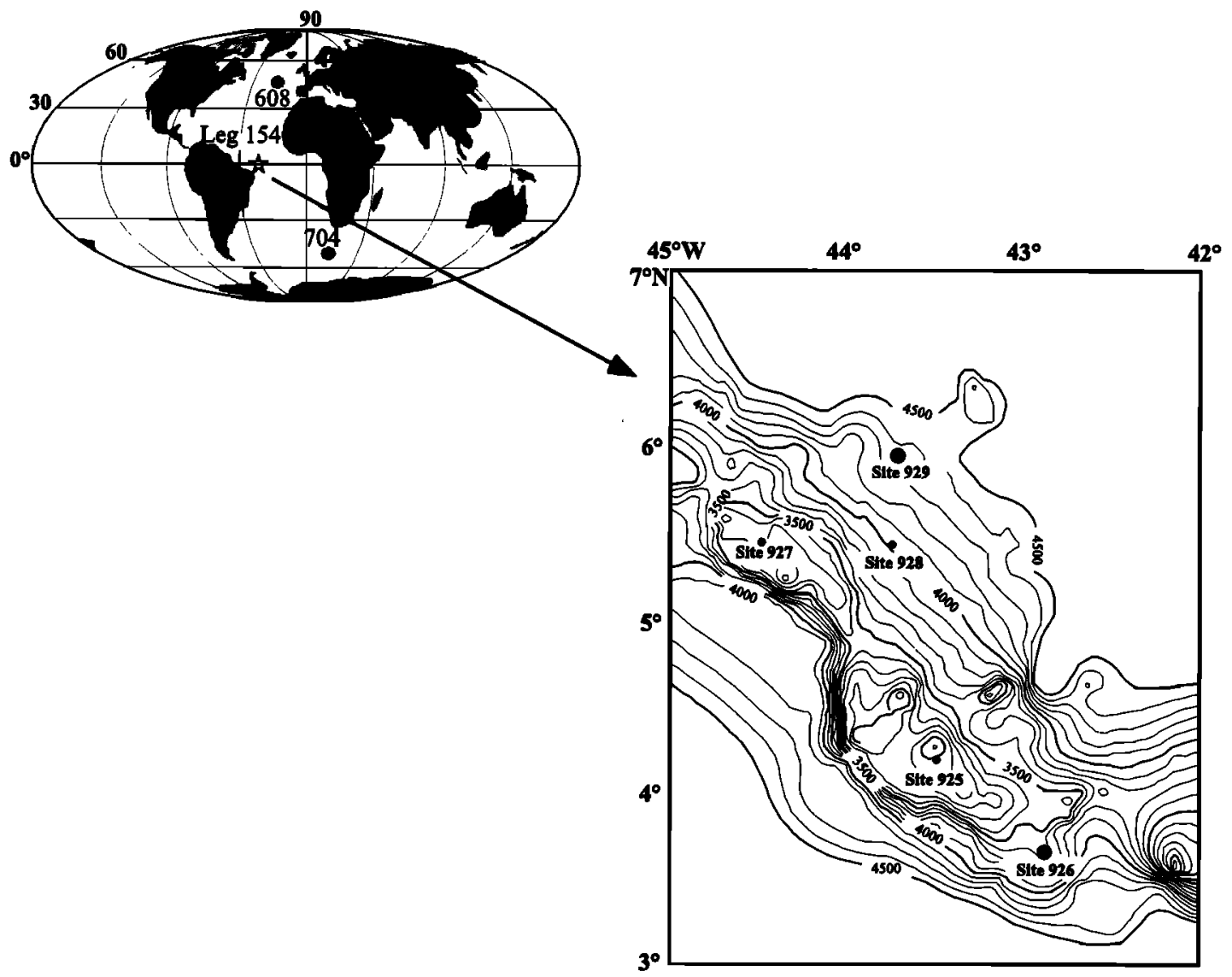

Figure 1. Ocean Drilling Program (ODP) Leg 154 location map and bathymetry of Ceara Rise showing depth transect of sites drilled ( $100-\mathrm{m}$ contour interval). Present-day positıons of sites 929 (4358 m water depth) and 926 (3598 $\mathrm{m}$ ) are highlighted. ODP sites 608 and 704 are also shown. 
Table 1. Position of the First Occurrence of Sphenolithus delphix and Sedimentation Rates at Sites 929 and 926 Used for Late Oligocene and Early Miocene Initial Age Model Determinations

\begin{tabular}{|c|c|c|c|c|}
\hline \multirow[b]{2}{*}{ Site Hole } & \multirow[b]{2}{*}{ Event } & \multicolumn{2}{|c|}{ Sample Range } & \multirow{2}{*}{$\begin{array}{c}\text { Mean Depth, } \\
\text { mbsf }\end{array}$} \\
\hline & & Top & Bottom & \\
\hline $\begin{array}{l}929 \text { A } \\
926 \text { B }\end{array}$ & $\begin{array}{l}\text { (T) Sphenolithus delphix } \\
\text { (T) Sphenolithus delphix }\end{array}$ & $\begin{array}{l}35 X-2,120 \mathrm{~cm} \\
50 X-6,80 \mathrm{~cm}\end{array}$ & $\begin{array}{c}35 X-3,40 \mathrm{~cm} \\
50 X-6,110 \mathrm{~cm}\end{array}$ & $\begin{array}{l}323.45 \\
469.85\end{array}$ \\
\hline Site Hole & Cores & $\begin{array}{c}\text { Core Depths, } \\
\text { mbsf }\end{array}$ & \multicolumn{2}{|c|}{$\begin{array}{c}\text { Sedimentation Rate, } \\
\mathbf{m} / \mathbf{M y r}\end{array}$} \\
\hline $929 \mathrm{~A}$ & $\begin{array}{c}31 X-32 X \\
33 X-34 X \\
35 X-36 X \\
37 X-38 X \\
39 X\end{array}$ & $\begin{array}{l}281.65-298.75 \\
301.05-320.00 \\
320.45-339.40 \\
339.75-358.20 \\
359.05-367.93\end{array}$ & \multicolumn{2}{|c|}{$\begin{array}{l}17.6 \\
17.1 \\
16.5 \\
20.7 \\
18.8\end{array}$} \\
\hline $926 \mathrm{~B}$ & $\begin{array}{c}47 X \\
48 X-49 X \\
50 X-51 X \\
52 X-53 X \\
54 X-55 X\end{array}$ & $\begin{array}{l}432.40-441.15 \\
442.15-460.05 \\
461.50-480.40 \\
480.55-498.80 \\
499.95-518.40\end{array}$ & \multicolumn{2}{|c|}{$\begin{array}{l}30.7 \\
26.7 \\
26.2 \\
23.8 \\
24.2\end{array}$} \\
\hline
\end{tabular}

Biostratigraphic data are from Curry et al. [1995]; sedimentation rates are from Weedon et al. [1997].

between 19 and 24 Ma are as high as $15 \%$. In general, with the exception of a few centimeter-scale turbidites present at Hole 929A, redeposition and deformation of sediments is minimal at these sites [Curry et $a h, 1995$ ]. Detailed physical properties data, including magnetic susceptibility, color reflectance, and natural gamma ray emission, are available at $3-10 \mathrm{~cm}$ resolution for both sites. Preliminary examination of these high-resolution data sets revealed pronounced periodicity [Curry et al., 1995], suggesting that the Ceara Rise sites would be highly suitable for studies of orbital forcing.

\subsection{Age Model Chronostratigraphy}

The initial chronological framework for both sites 929 and 926 was established with calcareous nannofossil and planktonic foraminiferal data (Table 1). Due to the limited number of reliably calibrated late Oligocene and early Miocene biostratigraphic control points, this age model is inadequate for evaluation of the higher-frequency signal component of the spectra. We have since adopted a new astronomically calibrated timescale developed by Shackleton et al. [1999] for these sites. This timescale was established by correlating maxima of the high-frequency (41 kyr) magnetic susceptibility variations at each site to an insolation tuning target dominated by obliquity, but also containing a precession component (approximately equivalent to varying insolation at $65^{\circ} \mathrm{N}$ ) based on the orbital calculations of Laskar et al. [1993]. Following preliminary tuning, an absolute age was assigned to the section by fitting the Leg 154 records to the pattern of calculated obliquity using the long-period amplitude modulation of the precession signal. This astronomical chronology has since been used together with isotopic (this study) and biostratigraphic data from site 929 and Deep Sea Drilling Project (DSDP) site 522 to recalibrate the ages of key magnetochrons near the Oligocene/Miocene boundary [Shackleton et al., 2000]. We recognize that the spectral peaks, particularly obliquity, may be enhanced as a consequence of the tuned age model, though the significance of regular cyclicity with depth in these sediments was observed prior to orbital fine tuning [Curry et al., 1995; Shackleton and Crowhurst, 1997].

\section{Methods}

Oxygen and carbon isotope ratios were measured from a -5-Myr section ( 20.5-25.4 Ma) spanning the Oligocene/Miocene boundary. At site 929 (cores 929A-31X39X, 282-368 meters below sea floor (mbsf)), samples were collected at $10-\mathrm{cm}$ intervals from each core translating to a temporal resolution of 4.5-5.5 kyr. At site 926 a slightly shorter, -3.3-Myr interval was examined, spanning 21.7-24.9 Ma (cores 926B-47X-55X, $433-518 \mathrm{mbsf}$ ). Samples were obtained every $60-80 \mathrm{~cm}$ (two samples per section), providing a temporal resolution of $\mathbf{2 0 - 3 0} \mathrm{kyr}$. In addition, core $50 \mathrm{X}$ from site 926 was sampled at $10-\mathrm{cm}$ intervals to increase the resolution of the planktonic foraminiferal record across the Mi- 1 event at the O/M boundary.

Sediments were first freeze-dried and weighed, soaked in a dilute sodium hexametaphosphate solution, and then placed on an orbital shaker at $200 \mathrm{rpm}$ for 2 hours to promote further disaggregation. Samples were washed through a $63-\mu \mathrm{m}$ sieve with deionized water, and the remaining coarse fraction was washed onto a filter, dried at room temperature, and reweighed. At site 929 the coarse fraction consists mostly of $\mathrm{CaCO}_{3}$ fragments and foraminifera shells and the coarse fraction weight percent is used as a semiquantitative preservation/dissolution index. Benthic foraminiferal stable Isotope stratigraphies were constructed for both sites using between three and six specimens of Cibicidoides mundulus picked from the $>150-\mu \mathrm{m}$ size fraction of each sample. Planktonic foraminiferal species Globigerinoides primordius were picked from the $>300-\mu \mathrm{m}$ size fraction of site 926 samples. This species is inferred to be an ancestor of Globigerinoides sacculifer, a modem surface-dwelling species [Bé, 1977; Hemleben et al., 1989]. Gs. primordius exhibited 
the lightest $\delta^{18} \mathrm{O}$ and heaviest $\delta^{13} \mathrm{C}$ isotopic values in a comparison of 12 planktonic foraminiferal species from the Ceara Rise [Pearson et al., 1997], indicating that it calcified in the upper mixed layer. Globigerina praebulloides, another mixed layer species [Pearson et al., 1997], was also analyzed because Gs. primordius was not present in all samples. All tests were cleaned with ultrasonic agitation to remove adhering sediment. Bulk sediment samples from site 926 were prepared by grinding $\sim 50 \mathrm{mg}$ of archived sediment and subsampling 200-300 $\mu \mathrm{g}$ for the isotopic analyses.

Samples were roasted at $375^{\circ} \mathrm{C}$ under vacuum and then reacted with phosphoric acid at $90^{\circ} \mathrm{C}$ using an automated, common acid bath system coupled to a Micromass-PRISM mass spectrometer. All isotopic data are reported in delta notation ( $\delta$ ) relative to the Vienna Peedee belemnite (VPDB) carbonate standard. Where replicate analyses were made, data are shown as the average of isotopic measurements. Analytical precision as determined from replicate carbonate NBS-19 standards $\left(-2.19 \%\right.$ for $\delta^{18} \mathrm{O}$ and $1.95 \%$ or $\left.\delta^{13} \mathrm{C}\right)$ analyzed during the period of data acquisition was better than $\pm 0.06 \%$ for $\delta^{13} \mathrm{C}$ and $\pm 0.08 \%$ of $\delta^{18} \mathrm{O}$.

Spectral and cross-spectral analyses between the records of $\delta^{18} \mathrm{O}, \delta^{13} \mathrm{C}$, percent coarse fraction, and magnetic susceptibility were performed on the site 929 data set using standard Blackman-Tukey statistical methods [Jenkins and Watts, 1968]. For these analyses the sign of $\delta^{18} \mathrm{O}$ is reversed following the convention of Imbrie et al. [1989], allowing for the calculation of phase relationships with respect to maximum interglacial conditions. Variance spectra were calculated over the entire time series consisting of 975 points with a constant 5-kyr sample spacing using 70 lags of the cross-covariance function. To resolve the lower-frequency components of the isotopic time series, locally weighted (15\%) means were fit to the data and subtracted to remove the longer term trends from each time series. Residual long-term trends were then removed using a linear detrend.

\section{Results}

\subsection{Site 929: High Resolution Time Series}

The stable carbon and oxygen isotope values of benthic foraminifera $C$. mundulus show distinct cyclicity over the entire interval of 20.5-25.4 Ma (Figure 2). On short timescales the oxygen isotope record is characterized by pervasive highfrequency oscillations with periods of roughly $40-50 \mathrm{kyr}$ and amplitudes of between 0.30 and $0.50 \%$. These highfrequency oscillations are superimposed on low-amplitude, lower-frequency oscillations with periods of several $100 \mathrm{kyr}$. On longer $\left(10^{6}\right.$ years $)$ timescales, between 25.0 and $23.4 \mathrm{Ma}$, $\delta^{18} \mathrm{O}$ values show relatively little change with average values around $0.95 \%$. Between 24.0 and $21.6 \mathrm{Ma}$, the dominant periods of low-frequency variability increase to $\sim 400 \mathrm{kyr}$. Beginning around $23.18 \mathrm{Ma}$, values increase by $\sim 1.69 \%$,

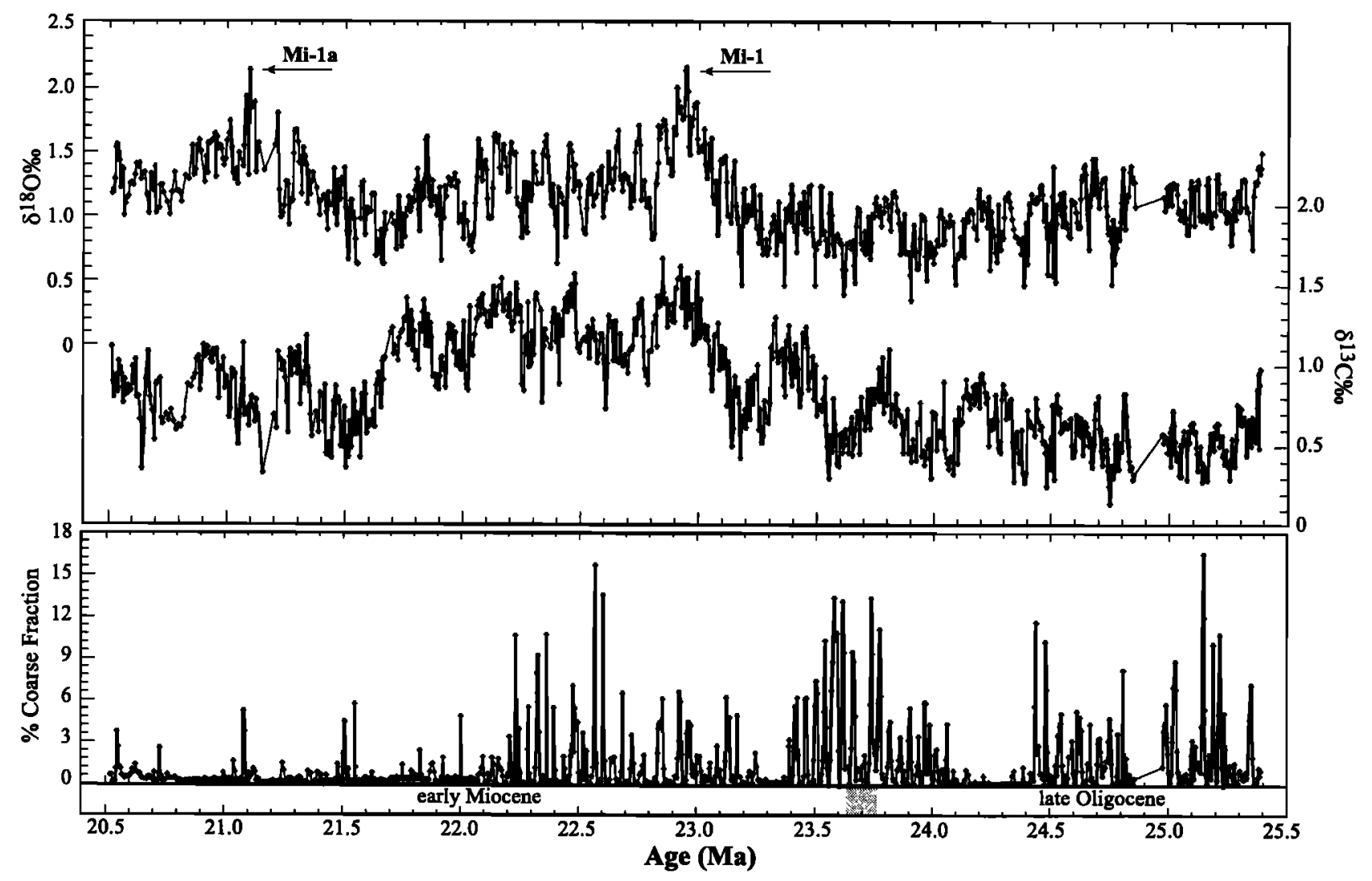

Figure 2. Site 929 benthic foraminiferal, $C$ mundulus, tume series of $\delta^{18} \mathrm{O}, \delta^{17} \mathrm{C}(\% c \mathrm{PDB})$, and percent coarse fraction (percent $>63 \mu \mathrm{m})$ data plotled versus age (20.4-25.5 Ma). Mi-1 and Mi-la events [Miller et al., 1991] and approximate tıming of the Oligocene/Miocene boundary are shown for reference. 


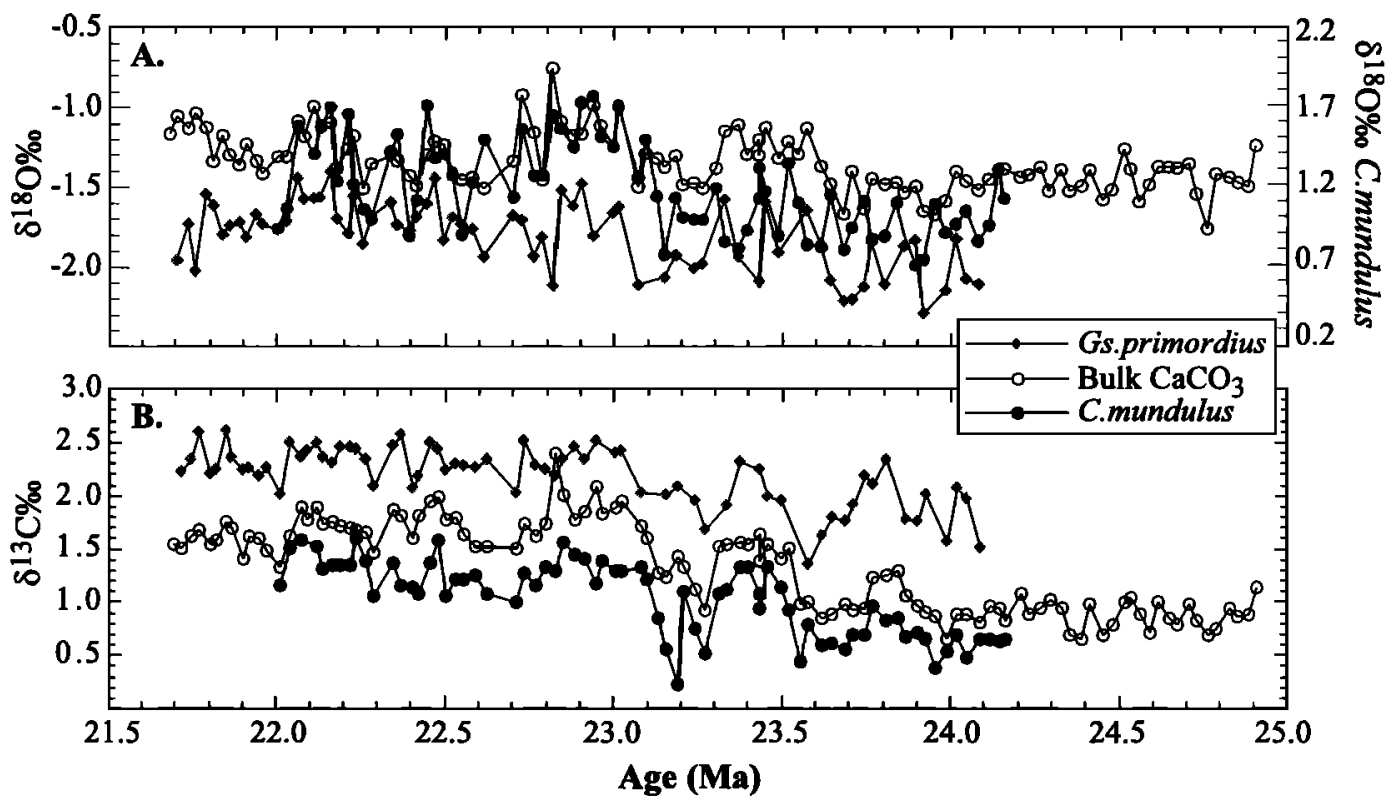

Figure 3. Site 926 (a) oxygen and (b) carbon stable isotope (\%c PDB) stratigraphies for benthic, $C$. mundulus, and planktonic, Gs. primordius, foramınifera and bulk sediment samples plotted versus age (21.5-25.0 Ma).

reaching a maximum of $2.16 \%$ at $22.95 \mathrm{Ma}$, the Mi-1 event of Miller et al. [1991]. A second large increase in $\delta^{18} \mathrm{O}$ values begins $\sim 21.6 \mathrm{Ma}$ and reaches a maximum of $2.14 \%$ at $\sim 21.1$ Ma, Mi-la of Wright and Miller [1992]. Both peaks are sustained for only a brief period of time $(-20 \mathrm{kyr})$ before declining.

The carbon isotope record shows a long-term increase from $\sim 24.0$ to 22.9 Ma with $\delta^{13} \mathrm{C}$ values changing from a mean of $0.50 \%$ to $1.30 \%$ (Figure 2). This long-term trend in carbon isotopes is not monotonic but is comprised of a series of lowfrequency cycles with periodicities of roughly $400 \mathrm{kyr}$. The amplitude of low-frequency cycles appears to increase slightly through time, reaching a maximum that is nearly coincident with the maximum in $\delta^{18} \mathrm{O}$ values at $\sim 22.9 \mathrm{Ma}$. Following this concurrent maximum in $\delta^{13} \mathrm{C}$ and $\delta^{18} \mathrm{O}$ values at $\mathrm{Mi}-\mathrm{I}$, the average carbon isotopic composition remains higher than the pre-24 Ma average until after the Mi-1a event. In addition, higher-order variations with periodicities around $40 \mathrm{kyr}$ are superimposed on the low-frequency cycles.

The site 929 record of coarse sand size fraction (CF; percent $>63 \mu \mathrm{m})$ is also characterized by cyclic, highfrequency variability with periods of $\sim 40 \mathrm{kyr}$. Values typically vary between 0.1 and $16 \%$, with several extended periods of extreme minima $(<1 \%)$ centered near $24.3,23.3,21.9$, and $20.9 \mathrm{Ma}$. Unlike the carbon and oxygen isotope records, the CF record does not appear to exhibit regular variability at the lower-frequency cycles of 100 or $400 \mathrm{kyr}$, though variability at a longer periodicity, for instance $1 \mathrm{Myr}$, may be present.

\subsection{Site 926: Low-Resolution Time Series}

In most respects, the site 926 low-resolution, benthic foraminiferal isotope stratigraphy is very similar to that observed at site 929 (Figure 3). For instance, the benthic foraminiferal $\delta^{18} \mathrm{O}$ record shows a rapid increase of $-1.0 \%$ centered at $23.0 \mathrm{Ma}$. Values increase from roughly $0.77 \%$ o prior to $23.15 \mathrm{Ma}$ to $1.77 \%$ at $22.95 \mathrm{Ma}$. This record also shows a series of low-frequency (400 kyr) oscillations with amplitudes that are slightly lower than those at site 929 (see also Figure 6a). The site 926 bulk sediment and planktonic foraminiferal $\delta^{18} \mathrm{O}$ records both show similar increases around 23.0 Ma and similar frequency variability but with a noticeably lower amplitude than observed in the benthic foraminiferal time series. For example, from 23.08 to 22.91 $\mathrm{Ma}$, Gs. primordius $\delta^{18} \mathrm{O}$ increases from a minimum of $-2.13 \%$ to a maximum of $-1.49 \%$. This $~ 0.6 \%$ increase is substantially smaller than the $1.0 \%$ increase observed in the 926 benthic record and the $1.6 \%$ increase in the 929 benthic record. Moreover, the mean values in the Gs. primordius $\delta^{18} \mathrm{O}$ record increase only slightly over the long term, from $-1.5 \%$ in the late Oligocene to $-1.3 \%$ in the earliest Miocene. A similar pattern is also observed in the record of bulk $\delta^{18} \mathrm{O}$.

All three $\delta^{13} \mathrm{C}$ records at site $\mathbf{9 2 6}$ also exhibit parallel trends that are nearly identical to those of site 929 . The site $926 C$. mundulus $\delta^{13} \mathrm{C}$ values increase from a minimum of $0.2 \%$ at 23.2 Ma to a maximum of $1.6 \%$ at 22.8 Ma. Bulk $\delta^{13} \mathrm{C}$ values increase from a minimum of $0.65 \%$ o to a maximum of $2.4 \%$, coincident with the $\delta^{13} \mathrm{C}$ maximum in the benthic record. Similarly, $\delta^{13} \mathrm{C}$ values of Gs. primordius increase by $0.8 \%$, from a minimum value of $1.7 \%$ to a maximum of $2.5 \%$. These records indicate that the long-term changes in $\delta^{13} \mathrm{C}$, including the low-frequency oscillations, occurred over the entire water column.

\subsection{Spectral Analysis}

Spectral analyses of the site 929 records of $\delta^{18} \mathrm{O}, \delta^{13} \mathrm{C}$, and percent coarse fraction (Figure 4) reveal the strong influence of orbital insolation changes on climate variability across this interval. Both isotopic variables exhibit significant concentrations of variance in the Milankovitch bands of eccentricity $(\sim 400$ and $100 \mathrm{kyr})$. In particular, both spectra display especially well-defined peaks at the period of obliquity (41 kyr), with smaller and less distinct peaks near the 
precessional band frequencies (19-23 kyr). The percent coarse fraction record displays a strong 41-kyr cyclicity, with only weak concentrations of variance near the 100- and 23-kyr bands.
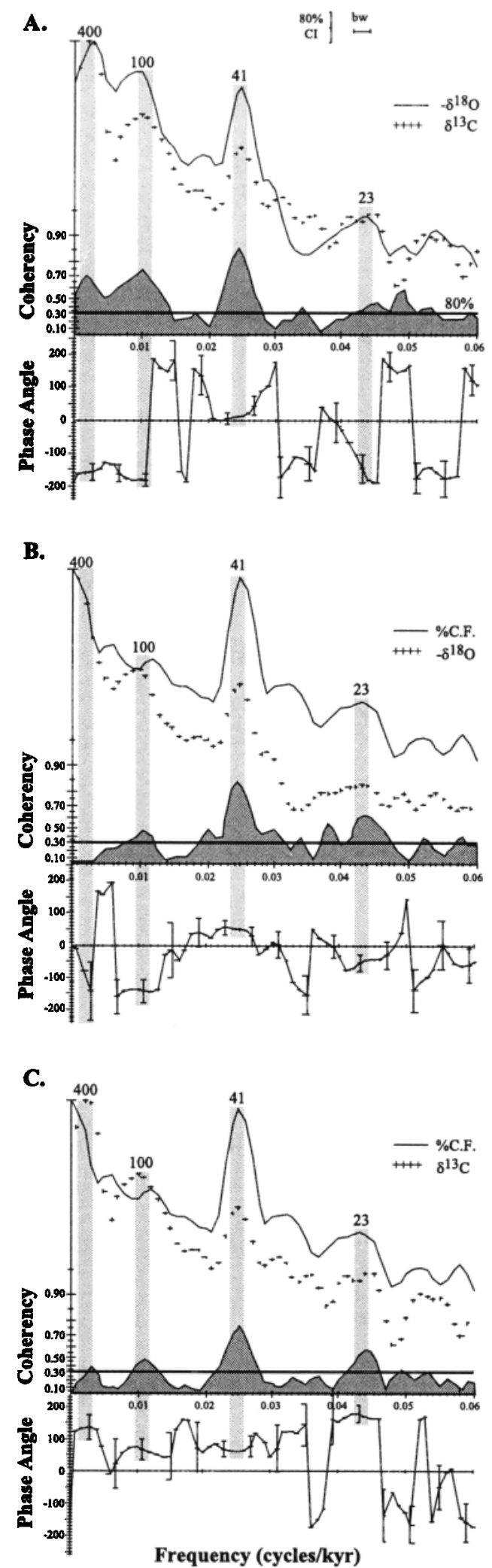

The site 929 cross spectra (Figure 4 and Table 2) show variance in $\delta^{13} \mathrm{C}$ to be coherent with $-\delta^{18} \mathrm{O}$ in all the primary orbital bands. In the 400- and 100-kyr low-frequency bands, $\delta^{18} \mathrm{O}$ maxima lead $\delta^{13} \mathrm{C}$ maxima by $\sim 25 \pm 15^{\circ}$ (Figure 5), indicating that glacials lead slightly (0-28 kyr) maxima in mean oceanic $\delta^{13} \mathrm{C}$. At higher frequencies the two isotopic variables are again highly coherent, particularly at the period of obliquity with maxima in $\delta^{13} \mathrm{C}$ essentially in phase or slightly lagging (0-2 kyr) interglacials (phase of $\left.14 \pm 8^{\circ}\right)$. Less pronounced coherency exists between the records at precessional frequencies, with phase relationships suggesting that maximum $\delta^{18} \mathrm{O}$ slightly leads maximum $\delta^{13} \mathrm{C}$ isotopic values.

Cross-spectral analyses of the site 929 oxygen isotope and percent coarse fraction and carbon isotope and percent coarse fraction time series produce similar results. Both show a lack of coherence at low frequencies but strong coherence at the 41-kyr period. Calculation of phase relationships suggests that high percent coarse fraction leads interglacial conditions by $47 \pm 10^{\circ}(\sim 5 \mathrm{kyr})$ and leads maximum $\delta^{13} \mathrm{C}$ by $66 \pm 10^{\circ}(\sim 7 \mathrm{kyr})$. Analysis of percent coarse fraction and magnetic susceptibility data from site 929 produces spectra (not shown) that are highly coherent at most frequencies lower than $0.05 \mathrm{kyr}^{-1}$ (period of $\sim 17 \mathrm{kyr}$ ) with calculated phase relationships consistently around $\pm 180^{\circ}$. These results indicate that the two latter parameters are essentially influenced by the same processes (i.e., dissolution and/or the relative flux of terrigenous material).

\section{Discussion}

The high-resolution $\delta^{18} \mathrm{O}$ and $\delta^{13} \mathrm{C}$ time series generated for site 929 allow for detailed examination of many aspects of late Oligocene to early Miocene climatic and oceanographic change, including the $\mathrm{Mi}-1$ and $\mathrm{Mi}-1 \mathrm{a}$ oxygen isotope excursions. Mi-1 is the first and largest in a series of step-like cooling episodes occurring in the early Miocene [Miller et al., 1987, 1991]. Similar increases have been identified in lowresolution benthic foraminiferal records from six Atlantic cores and in records of surface-dwelling planktonic foraminifera from two subtropical Atlantic sites. The Mi-1 and $\mathrm{Mi}-\mathrm{la}$ events, defined by their maximum $\delta^{18} \mathrm{O}$ values, were previously assigned ages of $23.8 \mathrm{Ma}$ [Berggren et al., 1995; Cande and Kent, 1995] and 21.2 Ma [Wright and Miller, 1992], respectively, on the basis of magnetostratigraphic and biostratigraphic correlations. Our astronomically calibrated ages for the same events, however, are 22.95 and $21.1 \mathrm{Ma}$, respectively.

At site 929 the $>1.6 \%$ excursion in $\delta^{18} \mathrm{O}$ values that defines Mi-1 (Figure 2) began around 23.18 Ma and continued for

Figure 4. Power spectra, coherency, and phase spectrums for the site 929 time series between the variables: $-\delta^{18} \mathrm{O}, \delta^{13} \mathrm{C}$, and percent coarse fraction (\%C.F.). Time series contained 975 points interpolated at 5 -kyr intervals and were analyzed with 70 lags of the cross-covariance function. Spectra have a resulting bandwidth of $0.002 \mathrm{kyr}^{-1}$. Variance is plotted on a log scale and coherency (dark shading) is significant above the $80 \%$ confidence line. Phase relationships are only meaningful where the two variables are coherent above the $80 \%$ confidence limit and show significant covariance. Primary Milankovitch frequencies have been highlighted for reference. 
Table 2. Cross-Spectral Analysis Results Between Site $929-\delta^{18} \mathrm{O}, \delta^{13} \mathrm{C}$, and Percent Coarse Fraction (\%CF) Time Series

\begin{tabular}{|c|c|c|c|c|c|c|c|c|}
\hline \multirow[b]{2}{*}{ Variables } & \multicolumn{2}{|c|}{$400 \mathrm{kyr}$} & \multicolumn{2}{|c|}{$100 \mathrm{kyr}$} & \multicolumn{2}{|c|}{$41 \mathrm{kyr}$} & \multicolumn{2}{|c|}{$23 \mathrm{kyr}$} \\
\hline & $\boldsymbol{k}$ & Phase & $\bar{k}$ & $\overline{\text { Phase }}$ & $\bar{k}$ & Phase & $k$ & Phase \\
\hline $\begin{array}{l}-\delta^{18} \mathrm{O} \text { and } \delta^{13} \mathrm{C} \\
\mathrm{C.F} \text {. and }-\delta^{18} \mathrm{O} \\
\mathrm{C.F} \text {. and } \delta^{13} \mathrm{C}\end{array}$ & $\begin{array}{c}0.71 \\
-- \\
0.42\end{array}$ & $\begin{array}{c}-148 \pm 12^{\circ} \\
-\overline{136 \pm 28^{\circ}}\end{array}$ & $\begin{array}{l}0.76 \\
0.50 \\
0.52\end{array}$ & $\begin{array}{c}-170 \pm 17^{\circ} \\
-127 \pm 22^{\circ} \\
72 \pm 17^{\circ}\end{array}$ & $\begin{array}{l}0.89 \\
0.86 \\
0.81\end{array}$ & $\begin{array}{c}14 \pm 8^{\circ} \\
47 \pm 10^{\circ} \\
66 \pm 10^{\circ}\end{array}$ & $\begin{array}{l}0.50 \\
0.62 \\
0.65\end{array}$ & $\begin{array}{c}-140 \pm 25^{\circ} \\
-44 \pm 16^{\circ} \\
167 \pm 5^{\circ}\end{array}$ \\
\hline
\end{tabular}

Note that $k$ is degree of coherency, only shown where variables are coherent above the $80 \%$ confidence limit (i.e., $>0.30$ ). Negative phase shows a lead of variable $y$ over variable $x$.

$\sim 250 \mathrm{kyr}$ before reaching a maximum of $2.16 \%$ at $22.95 \mathrm{Ma}$ that was sustained for $\sim 20 \mathrm{kyr}$. This was followed by a termination that took over $\sim 120 \mathrm{kyr}$. In contrast, the Mi-la event is characterized by a more gradual increase in $\delta^{18} \mathrm{O}$ values, occurring over a period of $\sim 400 \mathrm{kyr}$, and also a more gradual termination, though the actual maximum, $2.14 \%$, and magnitude of the event are almost the same as for Mi-1. In both cases the rise in values is punctuated by a series of regular $\sim 41-\mathrm{kyr}$, high-frequency oscillations in $\delta^{18} \mathrm{O}$. This pattern suggests that these events consisted of a sequence of minor glacial growth and decay episodes of increasing intensity superimposed on a lower-frequency cyclicity of $\sim 400$ kyr.

The covariance that exists between $\delta^{18} \mathrm{O}$ and $\delta^{13} \mathrm{C}$ at the 400-kyr cycle across the Oligocene/Miocene boundary (including the Mi-1 maximum) has not been observed in PlioPleistocene records [Imbrie and Imbrie, 1980; Rial, 1999]. The periodicity of coeval oscillations in both isotopic records suggests orbital pacing of global climate and ocean chemistry, yet the ubiquitous nature of the Mi-1 event and the preceding change in amplitude of the 400-kyr cycles suggest an amplification of the response by a shift in either the external (orbital) forcing or some feedback internal to the climate system (i.e., threshold ice sheet size or transient carbon reservoirs). High coherence between $\delta^{18} \mathrm{O}$ and $\delta^{13} \mathrm{C}$ at this period suggests that feedbacks from the global carbon cycle may have contributed to an exceptionally strong glaciation (Mi-1) at the Oligocene/Miocene boundary. We shall explore the possible nature of this feedback below.

\subsection{Ice Volume and Temperature}

The rapid increase and peak in oxygen isotopes between 23.2 and $22.8 \mathrm{Ma}$ occurs in all records from both sites 929 and 926 (Figure 6) and closely correlates in time with the prominent Mi-1 event as defined by Miller et al. [1991]. In principle, direct covariance between benthic and mixed layer planktonic foraminiferal $\delta^{18} \mathrm{O}$ records from a western equatorial site (i.e., site 926) should primarily reflect changes in ice volume [Shackleton and Opdyke, 1973; Miller et al., 1987]. Any differences in the amplitude of change are largely attributable to the effects of changing bottom water temperature.

Comparison of the site 926 benthic and surface-dwelling planktonic foraminiferal oxygen isotope records reveals strong covariance and a similar range of variability $(\sim 0.50 \%$ ) prior to the large increase at Mi-1 (Figure 3). This parallelism is consistent with an ice volume control on seawater $\delta^{18} \mathrm{O}$ during the late Oligocene and suggests a regular pattern of small ice sheet growth and decay. Recognizing that the low-resolution site 926 planktonic record probably does not capture the full amplitude of Mi-1 (defined by only eight data points), we increased the resolution of the Gs. primordius $\delta^{18} \mathrm{O}$ record across the peak of the event $(223.0-22.9 \mathrm{Ma})$ (Figure 7). This higher-resolution, planktonic record shows that the $\mathrm{Mi}-1 \delta^{18} \mathrm{O}$ excursion is not as large as recorded in the benthic record; nevertheless, it is of greater magnitude than previous isotopic shifts at 23.9 Ma, at $23.7 \mathrm{Ma}$, and at $23.4 \mathrm{Ma}$ (Figures 3 and 6). This suggests that $>50 \%$ of the Mi-1 excursion in the benthic record is due to ice volume.
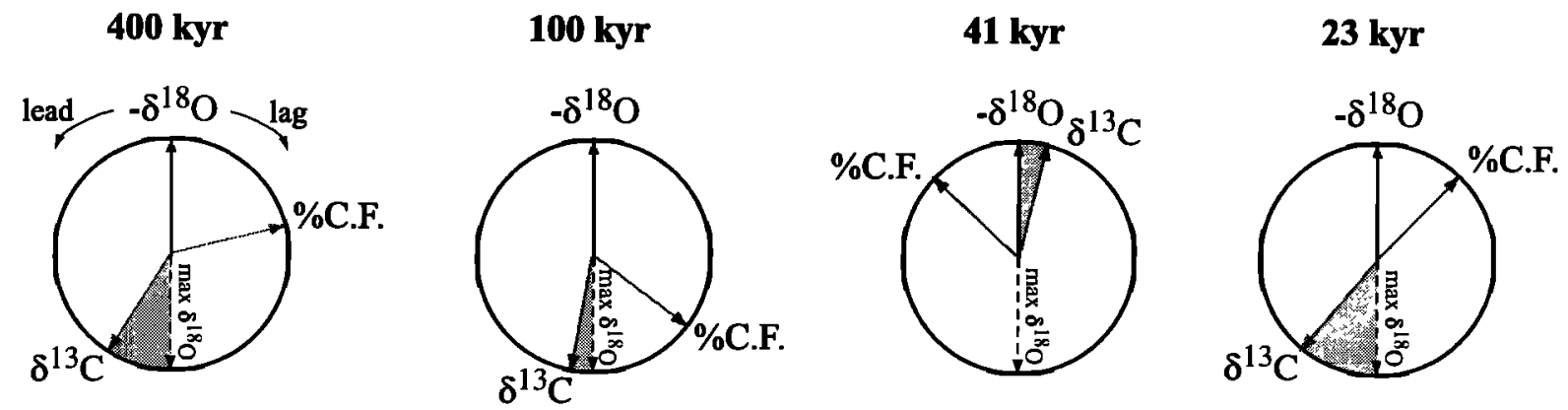

Figure 5. Phase relationships (Table 2) between maximum $-\delta^{18} \mathrm{O}$ (representıng periods of minimum ice; arbitrarıly set to $0^{\circ}$ ), $\delta^{13} \mathrm{C}$, and percent coarse fraction (\%C.F.) variables at the 400-, 100-, 41-, and 23-kyr periods. Arrows showing maximum $\delta^{18} \mathrm{O}$ (periods of maximum ice; exactly out of phase with minimum ice) are shown for reference. Shaded regions highlight the phase between the two isotopic parameters. 

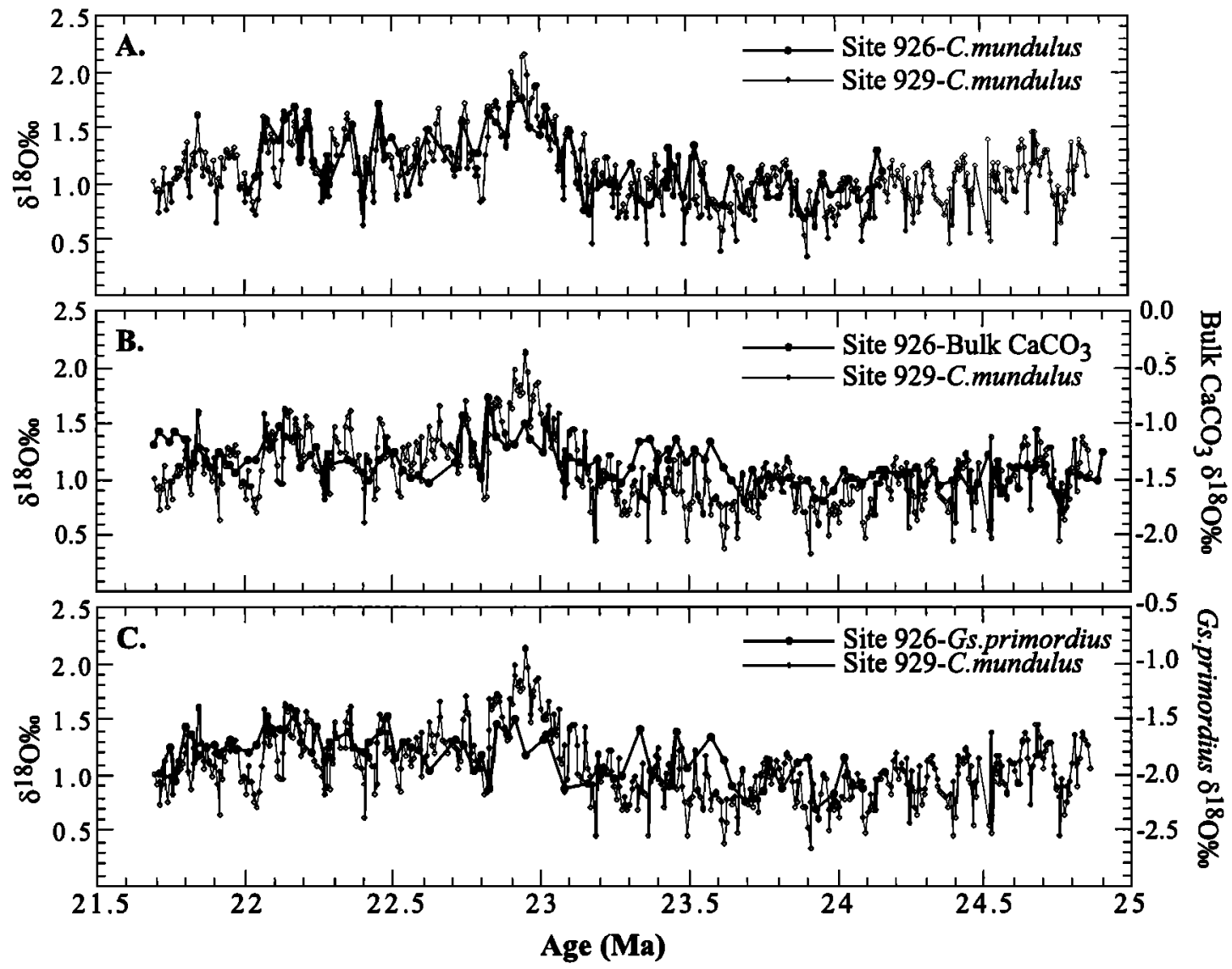

Figure 6. Site 929 high-resolution benthic foraminiferal, $C$. mundulus, $\delta^{18} \mathrm{O}$ time series compared to site $926 \delta^{18} \mathrm{O}$ of (a) benthic foraminifera, $C$. mundulus, (b) bulk $\mathrm{CaCO}_{3}$, and (c) planktonic foraminifera, Gs. primordius, plotted versus age (21.5-25.0 Ma).

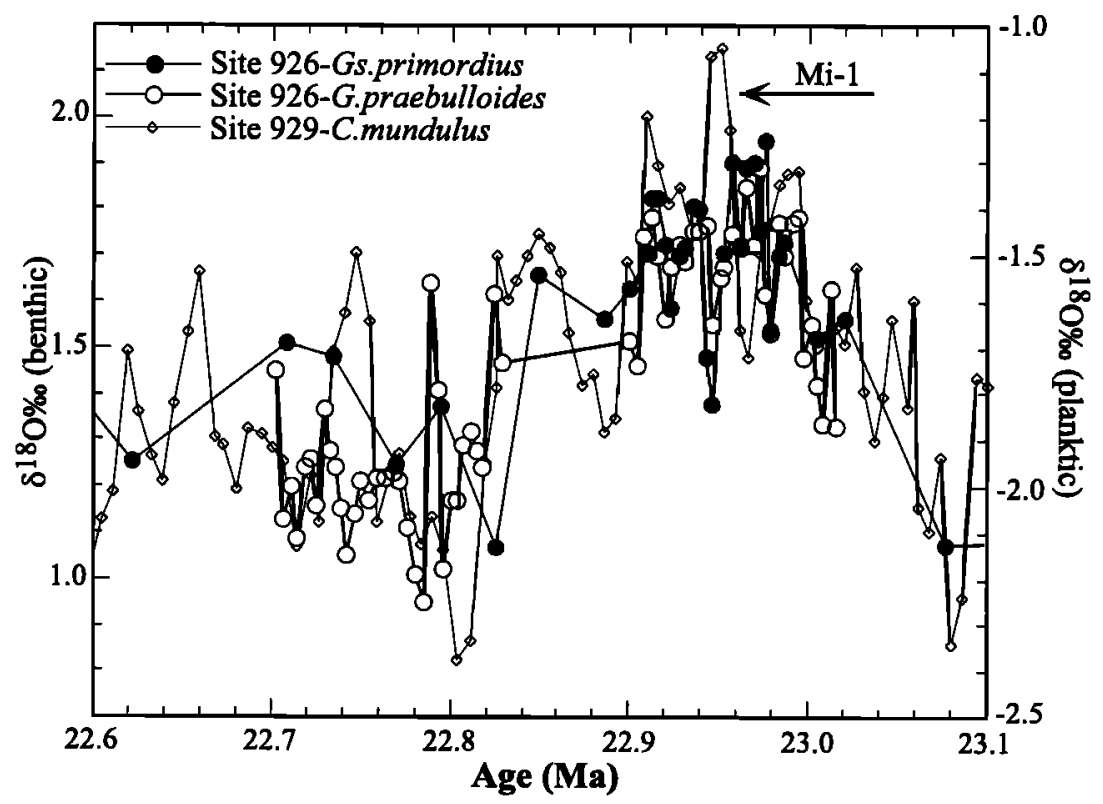

Figure 7. Site 926 Gs. primordius, hıgh- and low-resolution, and G. praebulloides, high-resolution, planktonic foramınıferal $\delta^{14} \mathrm{O}$ tume series compared to site 929 high-resolution, benthic foramınıferal, $C$. mundulus, values across the Mi-l interval (22 6-23 Ma). 
The ice volume effect on sea level can be roughly calculated using the late Pleistocene calibration of $0.11 \%$ o 10 $\mathrm{m}$ for $\delta^{18} \mathrm{O}$ to sea level [Fairbanks and Matthews, 1978] and by assuming constant temperature and salinity for surface waters above Ceara Rise. We estimate from the positive $\delta^{18} \mathrm{O}$ shift in the Gs. primordius record of $0.88 \%$ a minimum of 80 $\mathrm{m}$ of sea level lowering between 23.08 and $22.97 \mathrm{Ma}$ (though it should be noted that pre-Pleistocene sea level change can only be estimated to within a factor of 2 [Miller et al., 1987]). Based on the first-order $\delta^{18} \mathrm{O} /$ temperature relationship of $0.27 \% / 1^{\circ} \mathrm{C}$ for deep waters [Labeyrie et al., 1987] and using the residual benthic $\delta^{18} \mathrm{O}$ increase relative to the shift in planktonic foraminiferal $\delta^{18} \mathrm{O}$ at $\mathrm{Mi}-1(0.81 \%$ ), we compute $3.0^{\circ} \mathrm{C}$ of cooling at site 929 . The high-resolution reconstruction also shows that the maximum planktonic foraminiferal $\delta^{18} \mathrm{O}$ values at site 926 occur slightly earlier $(-75$ kyr) than the highest benthic foraminiferal values (Figure 7), implying that peak ice sheet growth preceded maximum deepwater cooling.

Miller et al. [1991], using low-resolution records ( -50 to 200-kyr sampling interval), found an increase in planktonic foraminiferal $\delta^{18} \mathrm{O}$ values that was of similar magnitude as the increase in benthic foraminiferal $\delta^{18} \mathrm{O}$. This shift is also larger than the total increase represented by the site 926 planktonic foraminiferal reconstruction. It is likely that the planktonic foraminiferal oxygen isotope ratios used by Miller et al.
[1991], derived from subtropical Atlantic DSDP sites 558 and 563 , were more strongly affected by changes in SST than ratios from western equatorial site 926. Supporting geological evidence also exists for substantial ice sheet expansion and sea level lowering at this time, including glacially deposited sediments on Antarctica [Leckie and Webb, 1986; Birkenmajer, 1987] and the correlation of $\mathrm{Mi}-1$ to a major sequence boundary on the New Jersey Margin [Miller et al., 1996].

\subsection{Carbon Isotope Cycles}

The long-term transition toward higher carbon isotope values and the low-frequency $\sim 400$-kyr oscillations recorded at sites 926 and 929 (Figure 8) is significant; they indicate potentially large-scale changes in the carbon chemistry of sea water. Because the changes were recorded by both planktonic and benthic organisms, they are consistent with a change in the mean carbon isotope composition of the basin and, most likely, the entire ocean. Evidence of similar positive excursions in lower-resolution records from the North and South Atlantic and Indian Oceans [Miller and Fairbanks, 1985; Wright et al., 1992] confirms the global scale of these cycles.

Over long timescales $\left(>10^{4}\right.$ years) the mean $\delta^{13} \mathrm{C}$ of the ocean dissolved carbon reservoir is controlled by the fluxes
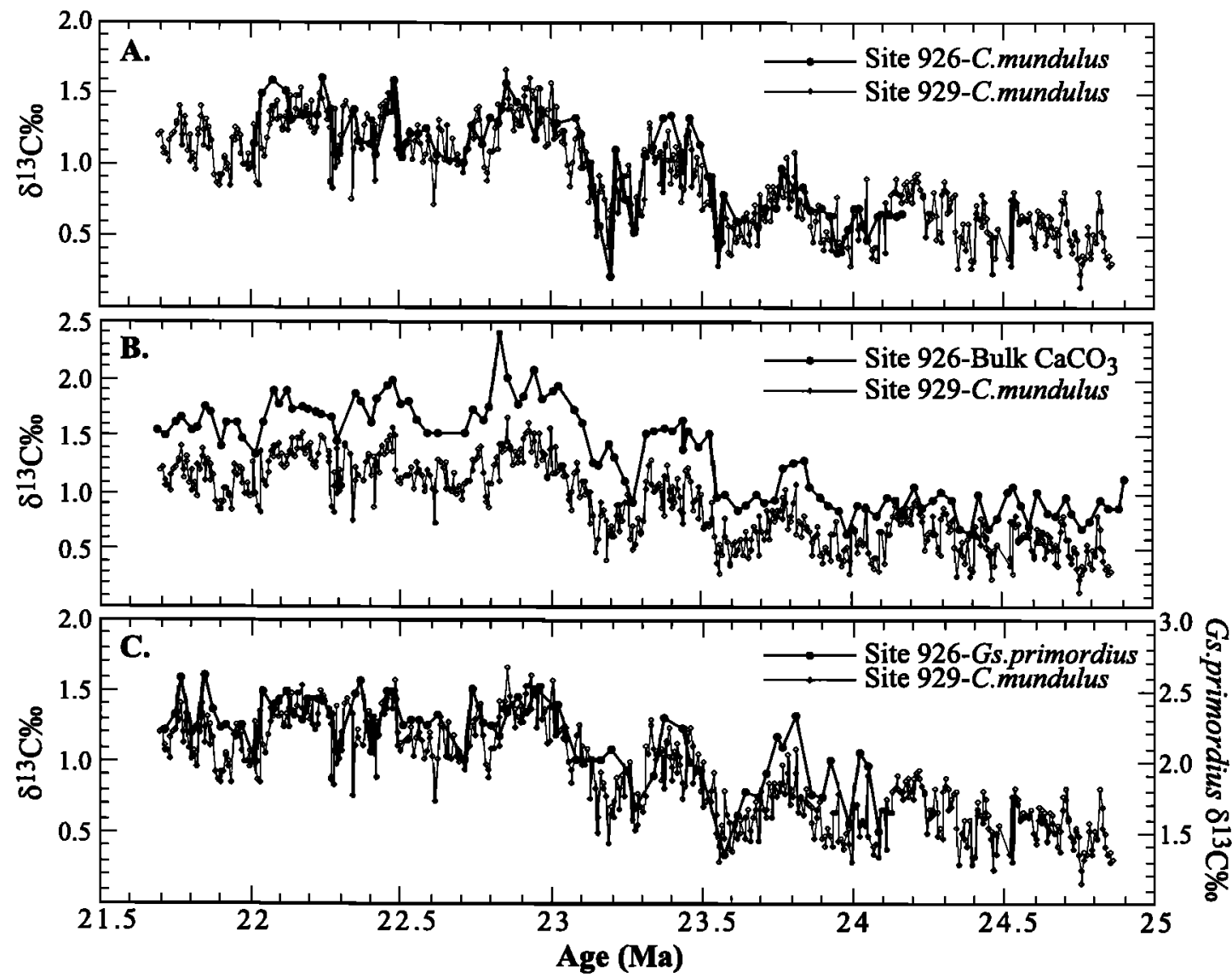

Figure 8. Site 929 hıgh-resolution benthic foraminiferal, $C$. mundulus, $\delta^{13} \mathrm{C}$ time series compared to site $926 \delta^{13} \mathrm{C}$ of (a) benthic foraminifera, $C$. mundulus, (b) bulk $\mathrm{CaCO}_{3}$, and (c) planktonic foraminifera, Gs. primordius, plotted versus age (21.5-25.0 Ma). 
and isotopic compositions of organic and inorganic carbon entering and leaving the ocean/atmosphere system. An $\sim 0.80 \%$ increase in the mean oceanic $\delta^{13} \mathrm{C}$ over several 100 $\mathrm{kyr}$, as observed at $\mathrm{Mi}-1$, could have resulted from any one of several perturbations to the global carbon cycle, including (1) an increase in mean river $\delta^{13} \mathrm{C}$ as influenced by weathering of carbon bearing rocks, (2) an increase in the ratio of organic carbon $\left(\mathrm{C}_{\mathrm{org}}\right)$ to carbonate $\left(\mathrm{C}_{\text {carb }}\right)$ burial in the deep sea, and/or (3) a decrease in the $\delta^{13} \mathrm{C}$ of $\mathrm{C}_{\text {carb }}$ and/or $\mathrm{C}_{\text {org }}$ buried relative to sea water $\delta^{13} \mathrm{C}$ [Miller and Fairbanks, 1985; Shackleton, 1987]. For example, assuming a carbon inventory similar to the modern ocean $(-38,000 \mathrm{Gt})$, an $0.8 \%$ increase could be achieved by the removal of an additional $1200 \mathrm{Gt}$ of $\mathrm{C}_{\text {org }}$ $(\sim-25 \%$ o).

Clues to the possible origin of the short- and long-term carbon isotope variations may lie in the relative timing and magnitude of these changes, in particular, the 400-kyr periodicity. Similar cycles have been recognized in carbon isotope records of the Oligocene and early to middle Miocene [Pisias et al., 1985; Woodruff and Savin, 1991; Flower and Kennett, 1993; Zachos et al., 1996]. Carbon isotope oscillations of this magnitude reflect on changes in the global carbon cycle, such as variations in atmospheric $\mathrm{CO}_{2}$, changes in organic and inorganic carbon burial, the weathering of $\mathrm{C}$ bearing rocks, and/or rates of volcanic $\mathrm{CO}_{2}$ release. In the Ceara Rise records these low-frequency oscillations are most pronounced over the Mi-1 transitional interval. This observation and the statistical evidence for covariance between $\delta^{18} \mathrm{O}$ and $\delta^{13} \mathrm{C}$ values at low frequencies indicate a probable linkage between the carbon cycle and climatic changes. In addition, the correspondence (Figure 5) between $\delta^{18} \mathrm{O}$ and $\delta^{13} \mathrm{C}$ suggests that climate variations drive the changes in ocean $\delta^{13} \mathrm{C}$.

One possible linkage involves the effects of climate change (i.e., Antarctic continental glaciation) on ocean/atmosphere circulation and organıc carbon burial. In general, high-latitude glaciation and cooling tend to increase equator-to-pole thermal gradients, which stimulates more vigorous atmospheric and oceanic circulation. This, in turn, can lead to higher rates of surface divergence and upwelling, which should promote higher export production and, possibly, organic carbon burial [Zachos et al., 1997]. As discussed above, an increase in the rate of organic carbon burial would eventually drive ocean $\delta^{13} \mathrm{C}$ upward, all else being equal [Shackleton, 1987]. Covariance of $\delta^{13} \mathrm{C}$ and $\delta^{18} \mathrm{O}$ at low frequencies, with maximum $\delta^{13} \mathrm{C}$ lagging peak glacial conditions by $2-20 \mathrm{kyr}$, is consistent with this forcing mechanism.

Some evidence exists to support such coupling between late Oligocene-early Miocene climate and the global carbon cycle. Geochemical records from sediment deposits located on the southeast margin of the United States clearly indicate a major episode of widespread phosphogenesis and $\mathrm{P}$ deposition roughly coincident with Mi-1 [Compton et al., 1993]. This implies enhanced upwelling and higher productivity. In addition, the conditions under which phosphogenesis occurs would be favorable to the preservation of organic carbon. Other evidence for higher export production includes an increase in the percent organic carbon content of sediment at Hole 929A from 24.8 to $23.0 \mathrm{Ma}$, synchronous with the increase in $\delta^{13} \mathrm{C}$ values, and higher concentrations of biosiliceous fossils in Ceara Rise sediments [Curry et al.,
1995]. While the latter might be attributable to changes in preservation, it is also consistent with a transition toward higher productivity. In short, all evidence supports an increase in biogenic sediment production, burial, and preservation and may point to changes in deepwater chemistry occurring at this time.

Compton et al. [1993] have proposed several mechanisms for the apparent synchrony between early to middle Miocene phosphogenesis, the positive carbon isotope excursions, and climate. They suggest that the enhanced accumulation of phosphorus on the southeast margin of North America was prompted by a rise in sea level which induced topographic upwelling. This in turn increased organic carbon burial, subsequently drawing down atmospheric $\mathrm{CO}_{2}$, initiating cooling and glaciation. However, cross-spectral analysis of the site $929 \mathrm{C}$ and $\mathrm{O}$ isotope records (Figures 4 and 5) shows that the low-frequency periods of high $\delta^{13} \mathrm{C}$ actually correlate with, or slightly lag, sea level low stands (peak $\delta^{18} \mathrm{O}$ ) and not sea level high stands. This relationship suggests that the climatic cooling was leading, and thus driving, the excursions in oceanic $\delta^{13} \mathrm{C}$ during the Miocene.

A second mechanism proposed by Compton et al. [1993] attributes the early Miocene $\delta^{13} \mathrm{C}$ cycles to glacial/interglacial changes in the strength of Northern Component Water (NCW) which altered the distribution of nutrients in the deep Atlantic. For example, during glacial periods the strength of NCW weakens, allowing greater influx of nutrient-rich, southern component water (e.g., Antarctic Bottom Water (AABW)) into the North Atlantic, thus leading to greater productivity and carbon burial. Such a major change in deepwater circulation patterns should be apparent in the carbonate chemistry and carbon isotope patterns in the Atlantic basin [Oppo and Fairbanks, 1987; Curry et al., 1988]. To test this possibility, we compare the site $929(4358 \mathrm{~m})$ benthic foraminiferal $\delta^{13} \mathrm{C}$ record with published low-resolution records from site 608 $(3115 \mathrm{~m})$ in the North Atlantic, today dominated by North Atlantic Deep Water (NADW), and site $704(2351 \mathrm{~m})$ in the Southern Ocean, currently situated at the southern extent of NADW influence (Figure 9; see Figure 1 and Table 3 for relevant geographic data). These sites were correlated using the peaks of the sites 929 and 704 oxygen isotope cycles assuming a partial ice volume control on benthic foraminiferal $\delta^{18} \mathrm{O}$ as demonstrated above.

This comparison reveals a weak but relatively persistent north-south gradient in $\delta^{13} \mathrm{C}$ values that suggests movement of deep water from the Southern Ocean northward with heaviest $\delta^{13} \mathrm{C}$ values at site 704 , closest to the proximal source, and lightest $\delta^{13} \mathrm{C}$ values at site 608 . The site 929 values are generally intermediate to those of the two Atlantic endmembers, which is to be expected in the absence of a NCW contribution to Atlantic bottom waters. Furthermore, the site 929 and 926 isotopic values are more or less the same throughout this period (Figures 6 and 8), suggesting that both sites were bathed by the same deepwater mass throughout the interval studied. These conditions contrast with the modern bottomwater hydrography of Ceara Rise. Today the region is a site of deep-water mixing in which site 929 is dominated by AABW and site 926 is dominated by warmer, saltier NADW [Curry et al., 1988]. The results of the site comparison are consistent with those of Woodruff and Savin [1989], Wright et al. [1992], and Flower et al. [1997b] who found evidence of 


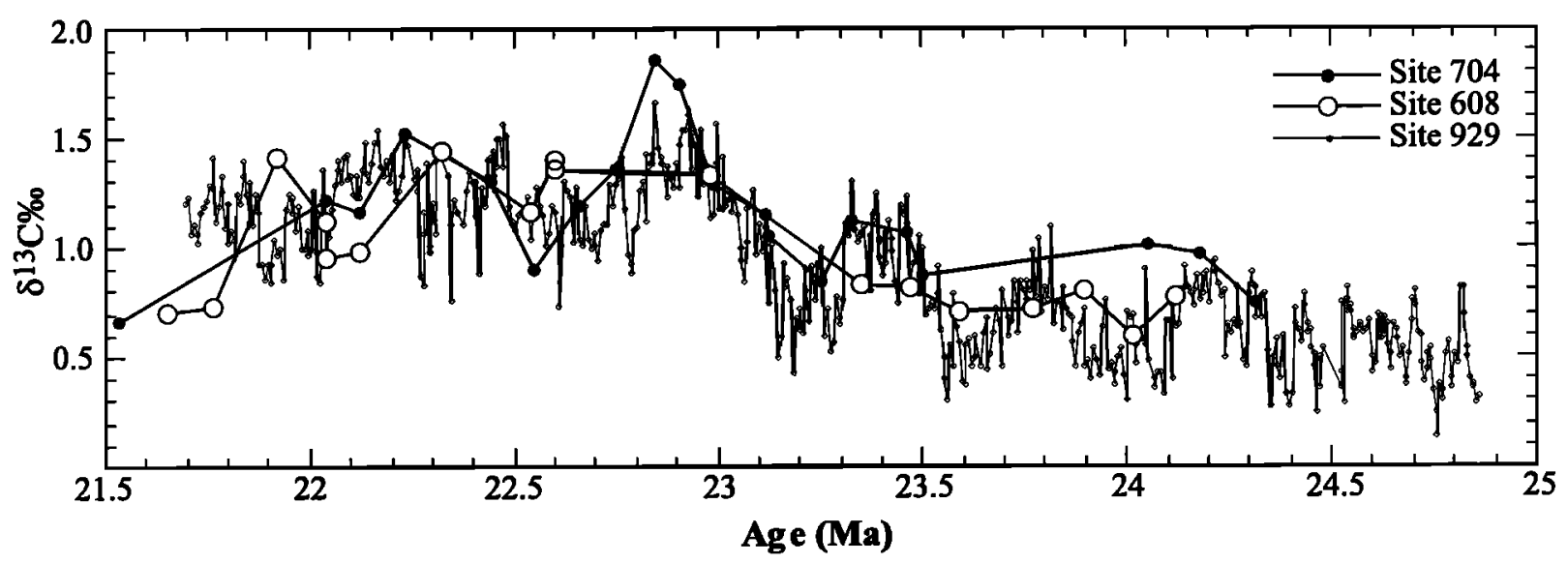

Figure 9. Benthic foraminiferal, $C$. mundulus, $\delta^{13} \mathrm{C}$ stratigraphies for sites 929,608 , and 704 plotted versus age (21.5-25.0 Ma).

increased water mass age from south to north in the Atlantic for much of the early Miocene. Given the available data, these results agree with theories suggesting a weak and shallow or nonexistent NCW source for the late Oligocene to early Miocene [Woodruff and Savin, 1989; Wright and Miller, 1993].

\subsection{Orbital Forcing in the Oligocene/Miocene}

Spectral analysis of the site 929 time series reveals significant concentrations of variance at the 400-, 100-, and 41-kyr periods (Figure 4), demonstrating that fluctuations in late Oligocene-early Miocene climate and ocean chemistry were strongly modulated by orbital forcing. The presence of prominent $41-\mathrm{kyr}$ peaks in the benthic $\delta^{18} \mathrm{O}$ spectra is consistent with a strong high-latitude control on climate variability [Berger and Loutre, 1991]. Lack of evidence for Northern Hemisphere glaciation and the absence of a NCW source to deep waters at this time point toward a dominant Southern Hemisphere control on climate oscillations in the obliquity band, presumably driven by fluctuations in Antarctic ice volume and/or deepwater temperatures. This finding, along with those of earlier studies documenting 41-kyr periods in late early Miocene and early Oligocene benthic $\delta^{18} \mathrm{O}$ records [Pisias et al., 1985; Zachos et al., 1996], supports the continued presence of ice sheets on Antarctica since at least the earliest Oligocene.

The strong response of climate and ocean carbon chemistry to eccentricity forcing at the 100 - and $400-\mathrm{kyr}$ periods as inferred from the Ceara Rise records is noteworthy.
Eccentricity modulates the high-frequency precession component of orbital forcing. However, the impact of eccentricity on insolation and subsequently the climate signal should be small [Berger et al., 1992]. However, at certain times (for instance, the last $800 \mathrm{kyr}$ ) the climate response at the period of eccentricity seems to increase. Several mechanisms have been proposed to explain this phenomena. For example, climate response to orbital forcing might be nonlinear. Internal feedbacks involving ocean/atmosphere circulation, the global carbon cycle, and ice sheet growth at the poles may contribute to this nonlinear response [Imbrie et al., 1993]. Another possibility is that the behavior of the orbital parameters through time is somewhat more chaotic than assumed [Matthews et al., 1997]. Potential interactions between other lower-frequency components of the orbital cycles need to be considered as well, including the 1.2-Myr obliquity cycle and the 2.3-Myr eccentricity cycle [Lourens and Hilgen, 1997].

A simple comparison of the site 929 isotopic time series with orbital parameters (Figure 10) shows that the long-period (400 kyr) maxima in $\delta^{18} \mathrm{O}$ and $\delta^{13} \mathrm{C}$ appear to coincide with $400-\mathrm{kyr}$ minima in orbital eccentricity. This association is most pronounced during the period 22.8-24.5 Ma, including the Mi-1 glacial maximum; the Mi-la event is an exception to this observation. The same appears to be true for the $-100-\mathrm{kyr}$ cycles as well. This suggests that the long-period $\delta^{18} O$ variations of the late Oligocene and early Miocene are phaselocked with orbital eccentricity cycles [Park and Maasch, 1993]. Also noteworthy is that both Mi-1 and Mi-1a occur

Table 3. Region, Latitude, and Depth of Sites Used in Deepwater Comparison

\begin{tabular}{cccc}
\hline DSDP/ODP Site & Paleolatitude (Region) & Depth, m & Reference Cited \\
\hline 929 & $5^{\circ} \mathrm{N}$ (west equatorial Atlantic) & 4358 & Curry et al. [1995] \\
926 & $3^{\circ}$ N (west equatorial Atlantic) & 3598 & Curry et al. [1995] \\
608 & $43^{\circ} \mathrm{N}$ (North Atlantic) & $3115^{\mathrm{a}}$ & Wright et al. [1992] \\
704 & $47^{\circ} \mathrm{S}$ (South Atlantic) & $2351^{\mathrm{a}}$ & Wright et al. [1992] \\
\hline
\end{tabular}

\footnotetext{
See Figure 1 for position of sites.
}

a Designates paleodepth. 

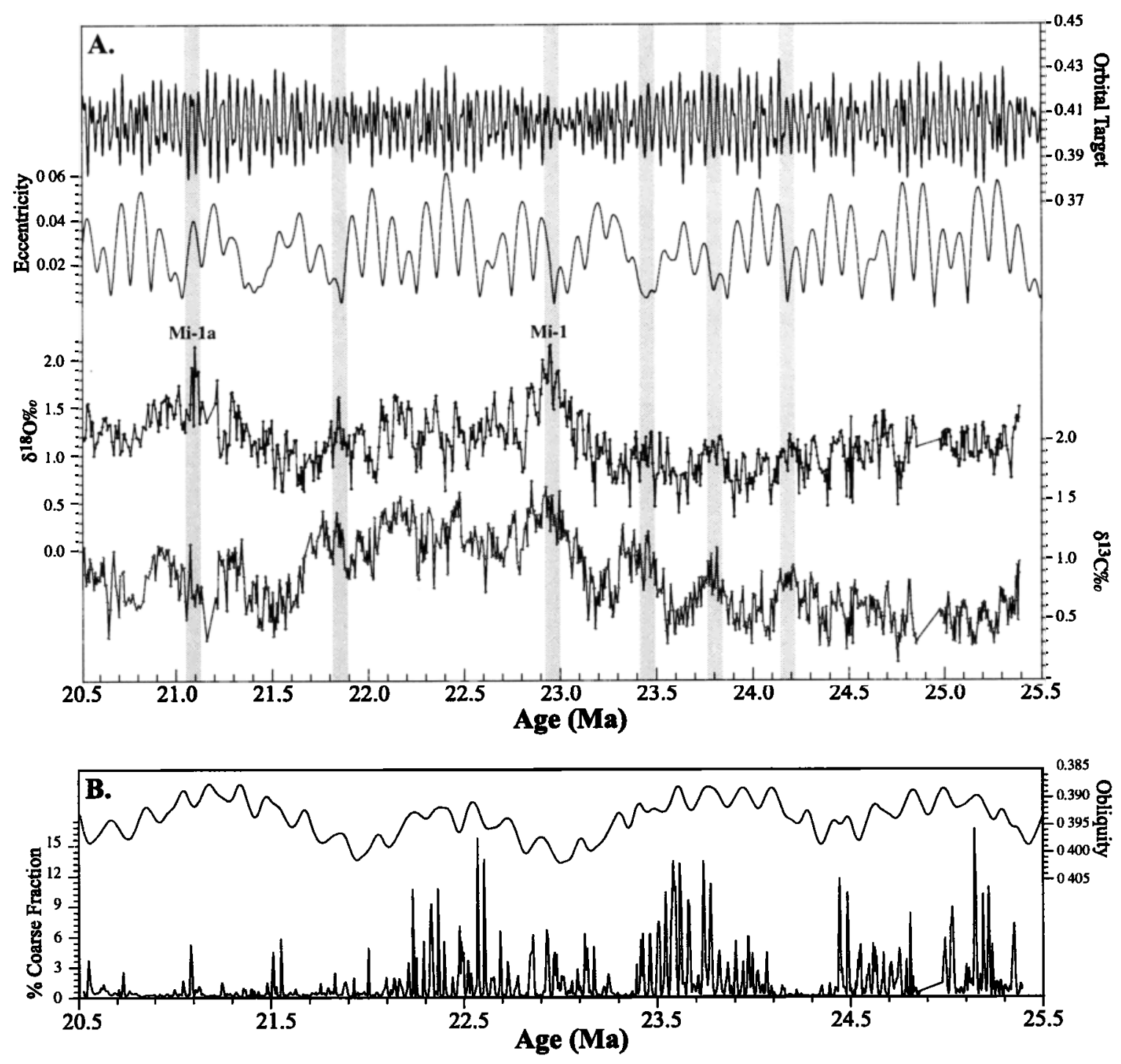

Figure 10. (a) Site 929 high-resolution benthic foraminiferal, $C$. mundulus, isotopic time series compared with orbital eccentricity and the orbital tuning target of Shackleton et al. [1999]. Shaded bars highlight peaks in $\delta^{18} \mathrm{O}$ for ease of comparison. (b) Site 929 percent coarse fraction (percent $>63 \mu \mathrm{m}$ ) compared with the 41-kyr minima of orbital obliquity (note inverted scale).

following (400 kyr) eccentricity cycles that contain 100-kyr oscillations with reduced amplitudes of variability. In contrast to results of Lourens and Hilgen [1997] who find a good correlation between third-order eustatic cycles and the 1.2-Myr cycle of Earth's obliquity in periods younger than $8.5 \mathrm{Ma}$, we see no obvious influence of the 1.2-Myr cycle on the isotopic time series over this interval, though it is interesting that $\sim 1.1$ Myr after Mi-1 ( $21.85 \mathrm{Ma})$, a peak in $\delta^{18} \mathrm{O}$ does occur.

Maxima in the long-term percent coarse fraction record, however, appear to coincide with minima in the record of obliquity (Figure 10), which occur at $\sim 1.2-\mathrm{Myr}$ intervals. This, in conjunction with the prominent spectral peak in percent $\mathrm{CF}$ at $41 \mathrm{kyr}$, suggests that seafloor carbonate dissolution varies with a cyclicity dominated by obliquity at this location, a pattern also observed in the upper Miocene [Shackleton and Crowhurst, 1997]. The phase relationship that exists at eccentricity frequencies is likely due to the response of the lysocline to lower-frequency changes in the global oceanic carbon reservoir.

From the records presented here it is clear that mean oceanic $\delta^{13} \mathrm{C}$ also covaried with climate at low and high frequencies throughout the latest Oligocene and early Miocene (Figure 4 and Table 2). Where coherent, variations in $\delta^{13} \mathrm{C}$ lead those in $-\delta^{18} \mathrm{O}$ at lower frequencies (i.e., 400 and $100 \mathrm{kyr}$ ) and lag at higher frequencies (i.e., $41 \mathrm{kyr}$ ) (Figure 5). Unique phase relationships in each orbital band suggest that different processes are responsible for climatic change at each frequency and with different timescales of forcing. However, strong covariance between $\delta^{18} \mathrm{O}$ and $\delta^{13} \mathrm{C}$ throughout the entire interval and at all orbital frequencies suggests strong coupling between glacial-interglacial changes (ice volume/sea level) and oceanic carbon chemistry at this location.

The phase relationship at $41 \mathrm{kyr}$ may be explained by several mechanisms including a transfer of biomass from the 
terrestrial to the marine realm and/or a change in ocean circulation patterns. Changing ocean circulation is probably not responsible for the lag in $\delta^{13} \mathrm{C}$ behind $-\delta^{18} \mathrm{O}$, as demonstrated in section 4.2. Alternatively, tropical deforestation coupled with an increase in runoff from land during deglaciation would introduce additional nutrients and light $\delta^{13} \mathrm{C}$ (plant biomass with an average $-25 \%$ ) to marine surface waters [Shackleton, 1977]. This would in turn enhance organic carbon production and burial, subsequently increasing oceanic $\delta^{13} \mathrm{C}$. Although the computed phase relationship is in agreement with this model, suggesting a time lag of 0-2 kyr for the change in ocean carbon isotopic composition following (Antarctic) deglaciation, additional climate and Geochemical records are required to establish the true nature of this coupling. Still, the high coherence between these two variables suggests that feedbacks from the global carbon cycle may have enhanced cooling, particularly the strong glaciation (Mi-1) at the $\mathrm{O} / \mathrm{M}$ boundary.

The high sensitivity of late Oligocene and early Miocene climate and ocean chemistry to the high-frequency components of orbital forcing is not unexpected. The presence of such variability in the Plio-Pleistocene, even after the initiation of large Northern Hemisphere ice sheets, suggests that these are stable components of forcing. The high power of the low-frequency components $(400 \mathrm{kyr})$ of cyclicity in the site 929 isotopic records, however, is not common to Pliocene, or more recent, time series. Rather, it appears to be a common feature of pre-Pliocene periods of unipolar glaciation such as the Miocene [Woodruff and Savin, 1991; Flower and Kennett, 1993]. The decrease in sensitivity of climate to the low-frequency eccentricity forcing at the end of the Miocene points to a fundamental shift in those Earth system parameters that influence climatic and oceanographic response to orbital forcing over the last $25 \mathrm{Myr}$. We speculate that changes in the locations and depths of the low- and highlatitude oceanic gateways during the Miocene and Pliocene were primarily responsible for this major shift in system sensitivity. Additional high-resolution records, particularly from the Pacific, are required to test this hypothesis.

\section{Summary}

High-resolution ( $-5 \mathrm{kyr}$ ) time series were generated for a -5-Myr interval spanning the Oligocene/Miocene boundary from site $929(4358 \mathrm{~m})$ on Ceara Rise in the western equatorial Atlantic. These records provide a detailed chronology of climatic and oceanographic change across this epoch boundary. In addition, lower-resolution ( $25 \mathrm{kyr})$ records from site $926(3598 \mathrm{~m})$, also on Ceara Rise, were constructed to constrain further changes in deep-ocean circulation and the global carbon system occurring at this time.
Detailed characterization of the $\mathrm{Mi}-1$ and $\mathrm{Mi}-\mathrm{la}$ oxygen isotope excursions [Miller et al., 1991;.Wright and Miller, 1992] shows that these large transient events were defined by $\sim 1.6 \%$ increases in $\delta^{18} \mathrm{O}$ values. In both cases, peak values $(\sim 2.15 \%$ o) were sustained for only $\sim 20 \mathrm{kyr}$ before declining. Based on comparison of paired benthic and planktonic foraminiferal records and using the Pleistocene calibration of $0.11 \%$ o $\delta^{18} \mathrm{O}$ per $10 \mathrm{~m}$ of sea level change, $\sim 80 \mathrm{~m}$ of sea level lowering is estimated for the Mi- 1 event accompanied by a decrease in deepwater temperatures of $3.0^{\circ} \mathrm{C}$ at site 929 . The site 929 oxygen isotopic record, including both Mi glaciations, is punctuated by regular, high-frequency oscillations in $\delta^{18} \mathrm{O}$. This feature, in addition to covariance in benthic and planktonic foraminiferal $\delta^{18} \mathrm{O}$ of $\sim 0.6 \%$, suggests cyclical variations in global ice volume and the continued presence of advancing and retreating ice sheets on Antarctica throughout the interval.

The long-term increase in mean oceanic $\delta^{13} \mathrm{C}$ is composed of several low-frequency ( $400 \mathrm{kyr})$ cycles that increase in amplitude toward the present, reaching maximum values that are coeval with the peak in $\delta^{18} \mathrm{O}$ at $\mathrm{Mi}-1$. Similar changes in $\delta^{13} \mathrm{C}$ exhibited by the records of benthic and planktonic foraminifera and bulk $\mathrm{CaCO}_{3}$ from site 926 strongly suggest that this transition represents a transformation of the global carbon system, most likely reflecting a change in organic carbon deposition/preservation. Coincidence of lowfrequency oscillations in $\delta^{13} \mathrm{C}$ and $\delta^{18} \mathrm{O}$ support a strong climatic influence on long-term carbon cycling. Lack of a vertical gradient between benthic carbon isotope values at sites 926 and 929 is consistent with theories suggesting a shallow and weak or nonexistent NCW source to bottom waters in the late Oligocene to early Miocene. Comparison of $\delta^{13} \mathrm{C}$ values with sites 608 (North Atlantic) and 704 (Southern Ocean) further supports this hypothesis and suggests a northward flow of deep water in the Atlantic basin at this time.

Spectral analyses of the site 929 time series show concentrations of variance in the orbital bands of eccentricity ( -400 and $100 \mathrm{kyr}$ ), obliquity (41 kyr), and precession (19-23 kyr), providing evidence for the strong modulation of climate by orbital forcing even with the equable conditions and lack of NCW during Oligocene-Miocene times. Presence of a strong 41-kyr peak in spectra of climatic parameters suggests a highlatitude control on climate and ocean chemistry variability, presumably Southern Hemisphere ice volume, consistent with the continued presence of ice sheets on Antarctica, at least since the late Oligocene.

Acknowledgments. We thank Peter Heitz, Katharina Billups, Melissa Harvey, Brenda Beitler, Geoff Koehler, Wendy Dahl, and Isabella Haller for technical support. We thank James Wright and Fritz Hilgen for their thoughtful reviews and Peggy Delaney and Christina Ravelo for comments on an earlier version of this manuscript. This research was supported by NSF grant EAR9725789 to J.C.Z. and B.P.F.

\section{References}

Bé, A.W.H., An ecologıcal, zoogeographical and taxonomic review of recent plankionic foraminifera, in Oceanic Micropaleontology, edited by A.T.S. Ramsay, pp. 1-100, Acad. Press, San Diego, Calıf., 1977.

Berger, A., and M.F. Loutre, Insolation values for the climate of the last 10 million years, Quat. Scl. Rev., 10, 297-317, 1991.
Berger, A., M.F. Loutre, and J. Laskar, Stability of the astronomical frequencies over the Earth's history for paleoclimate studies, Science, 255 , 560-566, 1992.

Berggren, W.A., D.V. Kent, C.C. Swısher III, and M.-P. Aubry, A revised Cenozoic geochronology and chronostratigraphy, in Geochronology, Time Scales and Giobal
Stratgraphic Correlatton, Spec. Pub. SEPM, Soc. Sediment. Geol., 54, 129-212, 1995.

Bırkenmajer, K., Tertiary glacial and interglacial deposits, South Shetland Islands, Antarctica: Geochronology versus biostratigraphy (a progress report), Bull. Pol. Acad. Sci. Earth Sci., 36, 133-145, 1987.

Cande, S.C., and D.V. Kent, Revised calibration 
of the geomagnetic polarity tumescale for the late Cretaceous and Cenozorc, J. Geophys. Res., 100, 6093-6095, 1995.

Compton, J.S., D.A. Hodell, J. Garrido, and D.J. Mallinson, Origin and age of phosphorite from the south-central Flonda platform: Relation of phosphogenesis to sea-level fluctuations and $\delta^{13} \mathrm{C}$ excursions, Geochim. Cosmochim. Acta, $57,131-146,1993$.

Curry, W.B., J.C. Duplessy, L.D. Labeyrie, and N.J. Shackleton, Changes in the distribution of $\delta^{13} \mathrm{C}$ of deep water $\Sigma \mathrm{CO}_{2}$ between the last glaciation and the Holocene, Paleoceanography, 3, 317-341, 1988.

Curry, W.B., et al, Proc. Ocean Drill. Program. Intial Reports, vol. 154, Ocean Dnll. Program, College Station, Tex., 1995.

Fairbanks, R.G, and R.K. Matthews, The marne oxygen isotopic record in Pleistocene coral, Barbados, West Indies, Quat. Res., 10, 181196, 1978.

Flower, B.P., and J.P. Kennett, Middle Miocene ocean-climate transition: High-resolutuon oxygen and carbon isotopic records from Deep Sea Drilling Project Site 599A, Southwest Pacific, Paleoceanography, 8, 811-843, 1993.

Flower, B.P, J C Zachos, and E. Martın, Latest Oligocene through early Miocene isotopic stratıgraphy and deep-water paleoceanography of the western equatonal Atlantic: Sites 926 and 929, Proc. Ocean Drill. Program Sct.Results, 154, 451-461, 1997a.

Flower, B.P., J.C. Zachos, and H.A. Paul, Milankovitch-scale clımate variability recorded near the Oligocene/Miocene boundary, Proc. Ocean Drill. Program Sci. Results, 154, 433$439,1997 \mathrm{~b}$.

Freeman, K.H, and J.M. Hayes, Fractionation of carbon isotopes by phytoplankton and estumates of ancient $\mathrm{CO}_{2}$ levels, Glohal Biogeochem. Cicles, 6, 185-198, 1992.

Haq, B U., J. Hardenbol, and P.R. Vall, Chronology of fluctuating sea levels since the Triassic (250 Million years ago to present), Science, 235, 1156-1167, 1987.

Hays, J.D., J. Imbrie, and N.J. Shackleton, Variations in the Earth's orbit: Pacemaker of the ice ages, Sclence, 194, 1121-1132, 1976.

Hemleben, C., M. Spindler, and O.R. Anderson, Modern Planktonic Foraminifera, SprngerVerlag, New York, 1989.

Hilgen, F.J., Astronomical calıbration of Gaus to Matuyama sapropels in the Mediterranean and implication for the geomagnetic polarity tumescale, Earth Planet. Sct. Lett., 104, 226244, 1991 .

Hodell, D.A., and F Woodruff, Variations in the strontium isotopic rato of seawater durng the Miocene: Strattgraphic and geochemıcal implications, Paleoceanography, 9, 405-426, 1994.

Imbrie, J., and J.Z Imbrie, Modeling the climatuc response to orbital variations, Sctence, 207. 943-953, 1980.

Imbne, J., J.D Hays, D.G. Martinson, A. McIntyre, A.C. Mıx, J.J Morley, N.G. Pisıas, W.L. Prell, and N J. Shackleton, The orbital theory of Pleistocene climate: Support from a revised chronology of the marine $\delta^{1 \mathrm{~B}} \mathrm{O}$ record, in Milankovitch and Climate, edited by A.L. Berger, et al., pp. 269-306, D. Reidel, Norwell, Mass., 1984.

Imbrie, J., A. McIntyre, and A. Mix, Oceanic response to orbital forcing in the late Quaternary: Observational and experimental strategies, in Climate and Geo-Sciences, edited by A. Berger, S. Schneider, and J C. Duplessy, pp. 121-164, Kluwer Acad., Norwell, Mass, 1989.

Imbne, J., et al., On the structure and origin of major glaciation cycles, 2 , The 100,000-year cycle, Paleoceanography, 8, 699-735, 1993
Jenkins, G.M., and D.G. Watts, Spectral Analysis and its Applications, Holden-Day, Memfield, Va., 1968.

Kennett, J.P., Cenozorc evolution of Antarctic glaciation, the circum-Antarctic Ocean, and their impact on global paleoceanography, $J$. Geophys. Res , 82, 3843-3860, 1977.

Labeyrie, L.D., J.C. Duplessy, and P.L. Blanc, Variations in mode of formation and temperature of oceanic deep waters over the past 125,000 years, Nature, 327, 477-482. 1987.

Laskar, J., F Joutel, and F Boudin, Orbital, precessional, and insolation quantitues for the Earth from -20 Myr to +10 Myr, Astron. Atrophys., 270, 522-533, 1993.

Leckie, M., and P.-N. Webb, Late Paleogene and early Neogene foraminufers of Deep Sea Drilling Project Site 270, Ross Sea, Inital Rep. Deep Sea Drill. Project, 90, 1093-1142, 1986.

Lourens, L.J., and F.J. Hilgen, Long-periodic variations in the Earth's obliquity and their relation to third-order eustatic cycles and late Neogene glaciatıons, Quat. Int., 40, 43-52, 1997.

Matthews, R.K., C. Frohlıch, and A. Duffy, Orbital forcing of global change throughout the Phanerozocic; a possible strattgraphic solution to the eccentncity phase problem, Geolog!, 25 , 807-810, 1997.

Mead, G.A., L. Tauxe, and J J. LaBreque, Oligocene paleoceanography of the South Atlantic: Paleoclmatic implications of sediment accumulation rates and magnetic susceptibility measurements, Paleoceanography, I, 273-284, 1986.

Miller, K.G., and R.G. Fairbanks, Ohgocene to Miocene carbon isotope cycles and abyssal circulation changes, in The Carbon Cycle and Atmospheric $\mathrm{CO}_{2}$ : Natural Variations Archean to Present, Geophys. Monogr. Ser., vol. 32 edited by E.T Sundquist and W.S. Broecker, pp. 469-486, AGU, Washington, D. C , 1985.

Miller, K.G., R.G. Fairbanks, and G.S. Mountain, Tertiary oxygen isotope synthesis, sea level history, and contınental margin erosion, Paleoceanography, 2, 1-19, 1987.

Miller, K.G. J.D. Wright, and RG. Farbanks, Unlocking the Ice House Oligocene-Miocene oxygen isotopes, eustasy, and margin erosion, J. Geophys. Res., 96, 6829-6848, 1991.

Miller, K.G., et al., Drilling and dating New Jersey Oligocene-Mocene sequences: lce volume, global sea level, and Exxon records, Science. 27I, 1092-I095, 1996

Oppo, D W., and R.G. Fairbanks, Variability in the deep and intermediate water circulation of the Atlanuc Ocean during the past 25,000 years: Northem Hemisphere modulation of the Southern Ocean, Earth Planet. Scl. Lett., 86, 1$15,1987$.

Paganı, M., M.A. Arthur, and K H. Freeman, Miocene evolution of atmosphenc carbon dioxide, Paleoceanography, 14, 273-292, 1999.

Park, J., and K.A. Maasch, Plio-Pleistocene ume evolution of the 100-kyr cycle in marine paleoclimate records, J. Geophys Res., 98. 447-46I, 1993.

Paul, H.A., A high-resolution stable isotope chronology of climate and ocean chemistry variabılity across the Oligocene/Miocene boundary, M.S. thesıs, Univ. of Calıf., Santa Cruz, 1997

Pearson, P.N., N.J Shackleton, G.P. Weedon, and M.A. Hall, Multuspecies planktonıc foraminifer stable isotope stratigraphy through Oligocene/Miocene boundary climatic cycles. Site 926, Proc. Ocean Drill. Program Sci. Results, I54, 441-449, 1997.

Pisıas, N.G., N.J. Shackleton, and M.A. Hall, Stable isotope and calcium carbonate records from hydraulic piston cored hole 574A: Highresolution records from the middle Miocene, Intial Rep. Deep Sea Drill. Project, 85, 735$748,1985$.

Pisias, N.G., and A.C. Mix, Aliasing of the geologic record and the search for long-period Milankovitch cycles, Paleoceanography, 3, 613-619, 1988.

Rial, J.A., Pacemaking the ice ages by frequency modulation of Earth's orbital eccentritity, Science, 285, 564-568, 1999.

Ruddiman, W.F., M. Raymo, and A. McIntyre, Matuyama 41,000-year cycles: North Atlantic Ocean and Northem Hemisphere ice sheets, Earth Planet. Scl. Lett., 80, 117-129, 1986.

Ruddiman, W.F., M.E. Raymo, D.G. Martinson, B.M. Clement, and J. Backman, Pleistocene evolution: Northern Hemisphere ice sheets and North Atlantıc Ocean, Paleoceanography, 4, 353-412, 1989.

Shackleton, N.J., and N.D. Opdyke, Oxygenisotope and paleomagnetic stratigraphy of equatorial Pacific Core V28-238: Oxygen isotope temperatures and ice volume on a $10^{5}$ to $10^{6}$ year scale, Quat. Res. N.Y., 3, 39-55, 1973.

Shackleton, N.J., and N.D. Opdyke, Oxygenisotope and paleornagnetic stratigraphy of Pacific Core V28-239 Late Pliocene to latest Plesstocene, in Investigations of Late Quatemary Paleoceanography and Paleoclimatology, edited by R.M. Cline and J.D. Hays, Mem. Geol. Soc. Am., 145, 449-464, 1976.

Shackleton, N.J., Carbon 13 in Uvigerina: Tropical rainforest history and the equatoral Pacific carbonate dissolution cycles, in The Fate of Fossil Fuel $\mathrm{CO}_{2}$ in the Oceans, edited by N.R. Anderson and A. Malahoff, pp. 401427, Plenum, New York, 1977.

Shackleton, N.J. The carbon isotope record of the Cenozouc: History of organic carbon burial and of oxygen in the ocean and atmosphere, in Marine Petroleum Source Rocks, edited by J. Brooks and A.J. Fleet, Spec. Publ. Geol. Soc., 26, 423-434, 1987.

Shackleton, N.J., and S. Crowhurst, Sediment fluxes based on an orbitally tuned time scale 5 Ma to $14 \mathrm{Ma}$. Site 926, in Proc. Ocean Drill. Program Scl. Results, 154, 69-82, 1997.

Shackleton, N.J., S.J. Crowhurst, G.P. Weedon, and J. Laskar, Astronomical calıbration of Oligocene-Miocene ume, Philos. Trans. $R$ Soc. London, Ser. A, 357, 1907-1929, 1999.

Shackleton, N.J., M.A. Hall, I. Raffi, L. Tauxe, and J.Z. Zachos, Astronomical calıbratıon age for the Oligocene-Miocene boundary, Geology, in press, 2000

Weedon, G.P., N.J. Shackleton, and P.N. Pearson, The Oligocene time scale and cyclostratigraphy on the Ceara Rise, western equatorial Atlantic, Proc. Ocean Drill Program Sci. Results, 154, 101-112, 1997.

Woodruff, F., and S.M. Savin, Miocene deepwater oceanography. Paleoceanography, 4, 87-140. 1989.

Woodruff, F., and S.M. Savin, Mid-Mrocene isotope stratigraphy in the deep sea: Highresolution correlations, paleoclimatic cycles, and sediment preservation, Paleoceanography. 6, 755-806, 1991.

Wright, J.D., and K.G. Miller, Miocene stable isotope stratigraphy, Site 747, Kerguelen Plateau, Proc. Ocean Drill. Program Sci. Results, I20, 855-866, 1992.

Wright, J D., and K.G. Miller, Southern Ocean influences on late Eocene to Miocene deepwater circulation, in The Antarctic Paleoenvironment: A Perspective on Global Change, Antarct. Res. Ser., vol. 56, edıted by J.P. Kennet and D.A. Warnke, pp. 1-25, AGU, Washington, D. C., 1993. 
Wright, J.D., K.G. Miller, and R.G. Fairbanks, Early and middle Miocene stable isotopes: Implications for deepwater circulation and climate, Paleoceanography, 7. 357-389, 1992

Zachos, J.C., T.M.Quinn, and K.A. Salamy, Highresolution $\left(10^{4}\right.$ years) deep-sea foraminiferal stable isotope records of the Eocene-Ohgocene climate transition, Paleoceanography, $I I, 251$ 266, 1996.

Zachos, J.C., B.P. Flower, and H.A. Paul,
Orbitally paced clumate oscillations across the Oligocene/Miocene boundary, Nature, 388, $567-570,1997$

B.P. Flower, Department of Marine Science, University of South Florida, St. Petersberg. FL 33701.

H.A. Paul, Gelolgical Institute, Swiss Federal Institute of Technology, ETH-Zentrum, CH-8092, Zurich, Switzerland. (hilary@erdw.ethz.ch)
A. Tripati and J.C. Zachos, Earth Science Department, University of California, Santa Cruz, CA 95064.

\section{(Received August 17, 1999; \\ revised April 11, 2000;}

accepted Apnl 11, 2000. 